\title{
Review: recent progress in low-temperature proton-conducting ceramics
}

\author{
Yuqing Meng ${ }^{1}$, Jun Gao ${ }^{1}$, Zeyu Zhao ${ }^{1}$, Jake Amoroso ${ }^{2}$, Jianhua Tong ${ }^{1}$, and Kyle S. Brinkman ${ }^{1,3, *}$ (1) \\ 'Department of Materials Science and Engineering, Clemson University, Clemson, SC 29634, USA \\ ${ }^{2}$ Savannah River National Laboratory, Aiken, SC 29808, USA \\ ${ }^{3}$ Center for Nuclear Environmental Engineering Sciences and Radioactive Waste Management (NEESRWM), Clemson University, \\ Clemson, SC 29634, USA
}

Received: 27 January 2019

Accepted: 20 March 2019

Published online:

9 April 2019

(C) The Author(s) 2019

\begin{abstract}
S
Proton-conducting ceramics (PCCs) are of considerable interest for use in energy conversion and storage applications, electrochemical sensors, and separation membranes. PCCs that combine performance, efficiency, stability, and an ability to operate at low temperatures are particularly attractive. This review summarizes the recent progress made in the development of low-temperature protonconducting ceramics (LT-PCCs), which are defined as operating in the temperature range of $25-400{ }^{\circ} \mathrm{C}$. The structure of these ceramic materials, the characteristics of proton transport mechanisms, and the potential applications for LT-PCCs will be summarized with an emphasis on protonic conduction occurring at interfaces. Three temperature zones are defined in the LT-PCC operating regime based on the predominant proton transfer mechanism occurring in each zone. The variation in material properties, such as crystal structure, conductivity, microstructure, fabrication methods required to achieve the requisite grain size distribution, along with typical strategies pursued to enhance the proton conduction, is addressed. Finally, a perspective regarding applications of these materials to low-temperature solid oxide fuel cells, hydrogen separation membranes, and emerging areas in the nuclear industry including off-gas capture and isotopic separations is presented.
\end{abstract}

\section{Introduction}

Protonic species $\left(\mathrm{H}^{+}\right)$require a lower activation energy to transport through solid-state crystal structures and associated interfaces due to the small ionic radius and the absence of an electron cloud as compared to other conducting ionic species such as oxygen ions $\left(\mathrm{O}^{2-}\right)$ [1]. Due to the combination of performance, efficiency, and stability in the lower temperature range, proton-conducting ceramics (PCCs) have attracted significant interest for applications in energy conversion [2-8], energy storage [9],

Address correspondence to E-mail: ksbrink@clemson.edu 
electrochemical sensors [10], and advanced gas separations [11-15]. In addition, there has been recent interest in PCCs as enabling technologies in the nuclear industry, including their use as PCCs for tritium sequestration, electrolysis, and separations [16].

Conventional materials used for solid oxide fuel cells (SOFCs) electrolytes are typically oxygen-ionconducting ceramics operated in a high temperature range $\left(\mathrm{HT}, 700-1000{ }^{\circ} \mathrm{C}\right)$. Degradation occurring at these temperatures and difficulties in high-temperature sealing of ceramic, glass, and metal components are the main causes for the limited solid oxide fuel cell (SOFC) commercialization at the present time. The high operating temperatures require the use of expensive interconnect materials, large energy input, and long start-up times [17]. This has driven the need for materials that produce a reasonable power output at intermediate temperatures (IT, $400-700{ }^{\circ} \mathrm{C}$ ) [1]. The lower activation energy of PCC materials has made them attractive candidates for electrolyte materials operating in the IT range $\left(400-700{ }^{\circ} \mathrm{C}\right)$. Numerous research works and several review papers on PCCs have recently focused on this IT range [1, 18, 19]. Zhang et al. [20] reviewed recent advances in SOFC materials and key components operating around $500{ }^{\circ} \mathrm{C}$, with a focus on the materials, structures, and technique development for IT-SOFCs. A recent book on proton-conducting ceramics was published in 2016 [21], which covered the fundamentals of proton hydration, transport properties, and some typical applications in the temperature range higher than $350{ }^{\circ} \mathrm{C}$. Kochetova et al. [22] thoroughly reviewed the PCC materials and applications at temperatures higher than $400{ }^{\circ} \mathrm{C}$. However, the further reduction in operating temperature (e.g., $<400{ }^{\circ} \mathrm{C}$ ) can further reduce system costs due to the wider range of material candidates for interconnects as well as the reduced balance of plant (BOP) costs. In addition, the long-term durability can also be improved by operating at decreased temperatures. In principle, the theoretical fuel cell efficiency can also be increased by reducing operating temperature [23].

In the past decade, some promising proton-conducting properties have been reported at temperatures lower than $400{ }^{\circ} \mathrm{C}$, with some of these studies even reporting room-temperature (RT) proton conduction. A common theme in the reports of lowtemperature proton conduction was the presence of nanometer-size grains resulting in enhanced grain boundary interfacial area. Furthermore, the electrical nature of these grain boundaries in nanostructured ionic conductors at low temperature has attracted considerable attention [24-26]. Park et al. [27] prepared nanostructured yttrium-doped barium zirconate $\left(\mathrm{BaZr}_{0.9} \mathrm{Y}_{0.1} \mathrm{O}_{3}\right)$ and investigated its grain and grain boundary protonic conductivity from RT to $400{ }^{\circ} \mathrm{C}$. Unexpectedly, high proton conduction was observed at low temperatures $\left(<100{ }^{\circ} \mathrm{C}\right)$ in the nanostructure. At the same time, interfacial proton conductivity in LT range has also been observed in simple oxide systems such as yttria-stabilized zirconia (YSZ) [28-31], ceria [25, 32-36], titania [37] which do not exhibit bulk proton conduction in the IT range. Miyoshi et al. [28] reported that the interfacial protonic conduction in nanostructured YSZ became noticeably high when the grain size was smaller than $100 \mathrm{~nm}$ and increased dramatically with decreasing grain size. The origin of the proton conductivity in these systems has been attributed to absorbed water at the grain boundary interfaces. The mechanisms of interfacial conduction have been used to describe LT conduction behavior and are schematically shown in Fig. 1. It is emphasized that the proton transport property is particular to its nanostructure that consists of nanograins connected with the interfacial hydrated layer, which serves as the pathway for interfacial protonic conduction rather than transport though bulk which occurs in the IT to HT regime.

In addition, several new classes of ceramic materials have been discovered to behave as proton conductors in the LT range: (1) Gui et al. [38] utilized the layered structure of phosphates to construct channels facilitating proton conduction below $300{ }^{\circ} \mathrm{C}$, (2) new $\mathrm{SiO}_{2}$-based composites have been found to exhibit proton conduction at room temperature [39], (3) Liu et al. [40] converted a lithium conductor to a proton conductor by ion exchange at low temperatures, and (4) Zhou et al. [41] devised a new doping strategy (electron doping) to develop high-performance $\mathrm{SmNiO}_{3}$ (SNO) perovskite proton conductors for LT solid oxide fuel cells.

Due to the growing number of researchers reporting details of interfacial proton conduction in LTPCCs, a systematic review would be useful given the large number of published works and recent scientific developments. This work fills the gap by providing review on proton-conducting ceramics in low temperature (LT, $25-400{ }^{\circ} \mathrm{C}$ ). Based on a review of the literature, three temperature zones are defined in 
Figure 1 Schematic

illustrations of hydrogen permeation a through a bulk material and $\mathbf{b}$ assisted by a hydrated, intergranular layer (interfacial conduction) that acts as a rapid transport pathway.
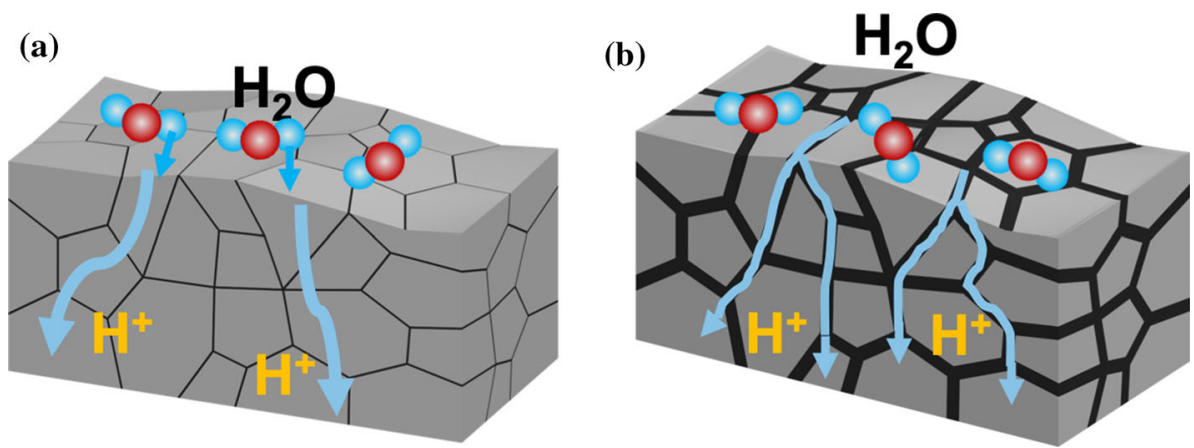

the LT-PCC operating regime based on the predominant proton transfer mechanism occurring in each zone. The variation in material properties such as crystal structure, conductivity, microstructure, fabrication methods required to achieve the requisite grain size distribution, along with typical strategies pursued to enhance the proton conduction is addressed. Finally, a perspective regarding applications of these materials to low-temperature (LT) solid oxide fuel cells, hydrogen separation membranes, and emerging areas in the nuclear industry including off-gas capture and isotopic separations is presented.

\section{Proton conduction at low temperature}

There are four possible proton transport pathways in PCCs: (1) transport in the bulk, (2) transport along the grain boundaries (GBs), (3) transport on the open pores surfaces in the absorbed water layer, and (4) transport in a proton-enriched layer directly below the pore/oxide interface (see Fig. 2) [32]. Due to limited water adsorption on the grain boundary when the temperature is higher than $500{ }^{\circ} \mathrm{C}$, proton conduction occurs mainly through bulk diffusion which has a smaller resistance than grain boundary diffusion. When the temperature is lower than $100{ }^{\circ} \mathrm{C}$, the residual open porosity is the key factor for the proton conductivity due to the enhanced physisorption reaction of water which occurs in this temperature range.

The amount of water adsorbed on an oxide surface is described by Langmuir and BET theory which depends on the thermodynamics of the water adsorption reaction [42, 43]. Norby et al. [44] investigated the structure of an absorbed water layer on surfaces of yttria-stabilized zirconia (YSZ) as a function of temperature and humidity. At $30 \%$ relative humidity (RH), the water layer consisted of three monolayers; two chemisorbed water layers and one physiosorbed water that in combination displayed an "ice-like" structure [45]. The chemisorbed water layer consisted of molecular adsorbed water hydroxyls which were stable up to temperatures near $600{ }^{\circ} \mathrm{C}$ and a hydrogen-bonded layer which was stable to temperature near $200{ }^{\circ} \mathrm{C}$. From 30 to $60 \% \mathrm{RH}$, there occurred a transition between "ice-like" structure and "water-like" structures for the second chemisorbed layer. Above $60 \% \mathrm{RH}$, the water molecules were similar to free liquid water. The proton conductivity in LTs depends on the nanostructure (e.g., grain size, porosity), humidity, and temperature (Table 1, 2).

\section{Hopping mechanism}

The proton conductivity behaviors in wet environments as a function of temperature for several model ceramic materials consisting of simple oxides, fluorite-type oxides, and perovskite-type oxides are shown in Fig. 3. For comparison, the typical dependence of the electrical conductivity on temperature in dry air for a micrometric polycrystalline zirconia is also included in this figure as a solid line. Three distinct regimes of conductivity or zones can be evidenced which correspond to the predominant proton conduction mechanism operating in these temperature regimes. These three different regimes physically correspond to differences in chemically and physically adsorbed water molecules bound to the surface of the oxide grains: Zone $1\left(T<50{ }^{\circ} \mathrm{C}\right)$ occurs where physical adsorption of water dominates; zone 2 $\left(50{ }^{\circ} \mathrm{C}<\mathrm{T}<150{ }^{\circ} \mathrm{C}\right)$ occurs where hydrogen bond network structure competes with physically adsorbed water; and zone $3\left(150{ }^{\circ} \mathrm{C}<\mathrm{T}<400{ }^{\circ} \mathrm{C}\right)$ occurs where chemical adsorption prevails [29]. In zone 1 and zone 2, and apparent negative activation energy 
Figure 2 a Schematic 2D representation of the microstructure of the porous nanocrystalline films. Four proton transport pathways are considered: 1 transport in the bulk, 2 along the GBs, 3 on the open pores surfaces in the absorbed water layer, and 4 in a proton-enriched layer right below the pore/oxide interface. b Detail of pathway 3. c Detail of pathway 4. Reprinted with permission from Gregori et al. [32].

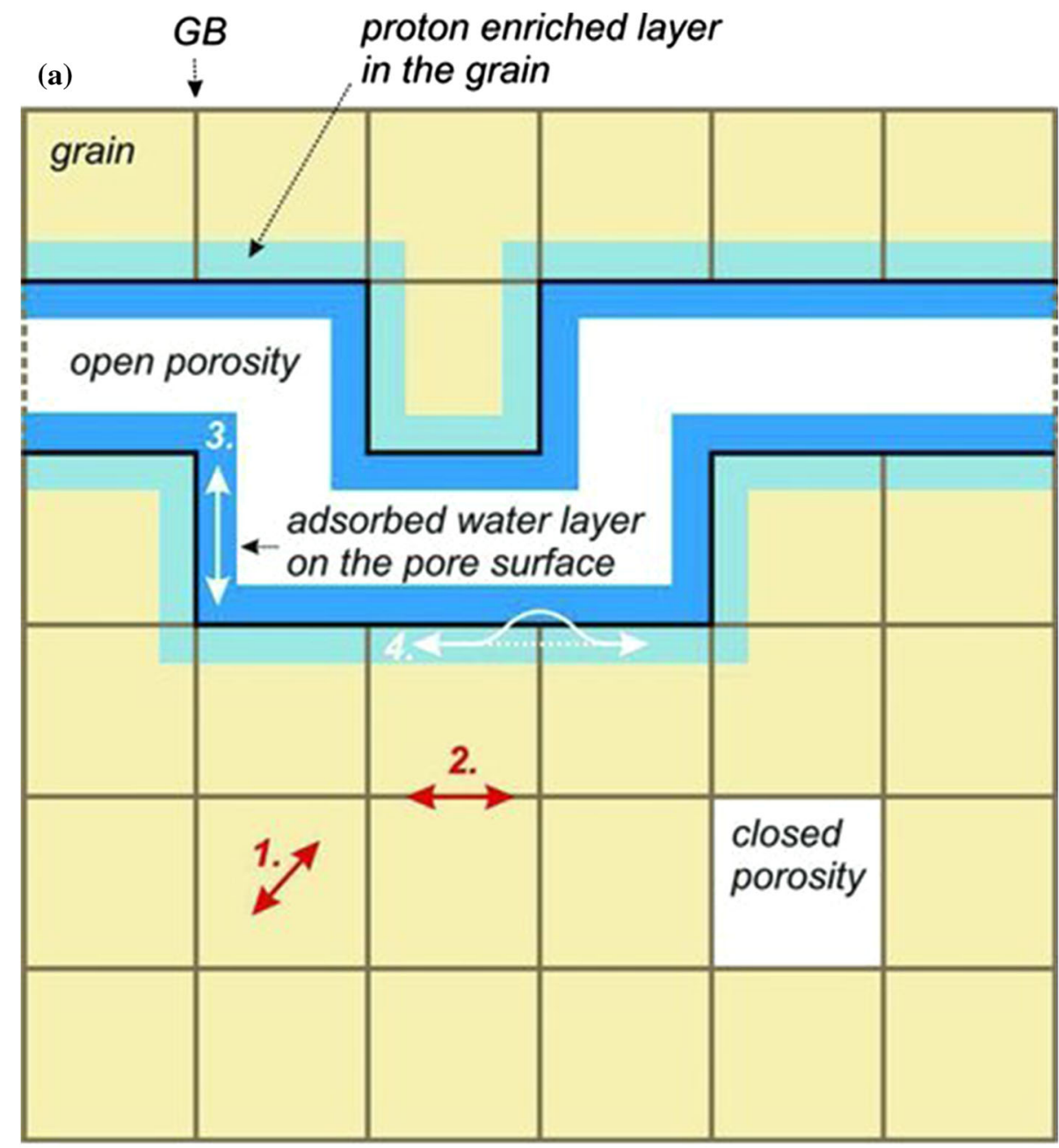

(b)

(c)

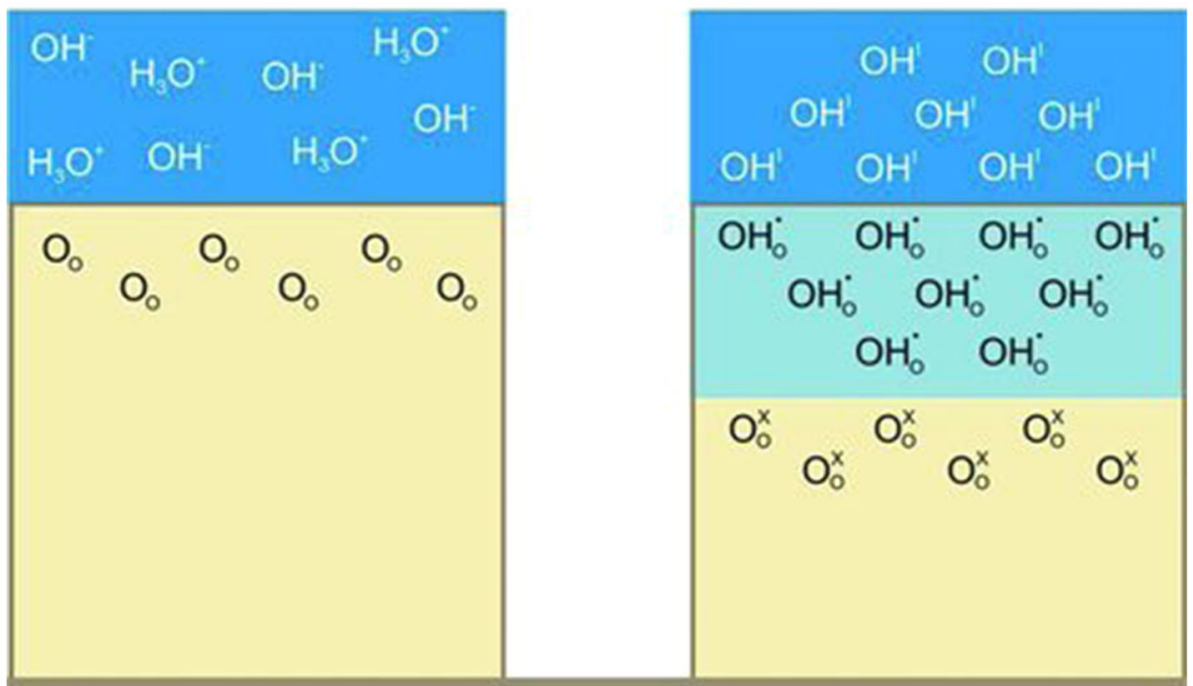


Table 1 Conductivity of doped perovskite-type proton conductors reported in the literature

\begin{tabular}{|c|c|c|c|c|c|}
\hline Materials & $\begin{array}{l}\text { Temp } \\
\left({ }^{\circ} \mathrm{C}\right)\end{array}$ & Conductivity $^{\mathrm{a}}(\mathrm{S} / \mathrm{cm})$ & $\begin{array}{l}\text { Measurement } \\
\text { conditions }\end{array}$ & $\begin{array}{l}\text { Activation } \\
\text { Energy }(\mathrm{eV})\end{array}$ & References \\
\hline $\mathrm{BaZr}_{0.25} \mathrm{In}_{0.75} \mathrm{O}_{3-\delta}$ & 300 & Total: $9.2 \times 10^{-5}$ & Hydrated & Bulk: 0.4 Total: 0.63 & [92] \\
\hline $\mathrm{BaZr}_{0.9} \mathrm{Y}_{0.1} \mathrm{O}_{3}$ & 300 & Gb: $8.7 \times 10^{-4}$ Bulk: $1.4 \times 10^{-3}$ & Wet $(10 \%)-\mathrm{Ar}-\mathrm{O}_{2}$ & GB:0.7-0.8 Bulk: 0.63 & [99] \\
\hline $\mathrm{BaZr}_{0.9} \mathrm{Y}_{0.1} \mathrm{O}_{3}$ & 300 & $\mathrm{~Gb}: 3 \times 10^{-4}$ & Wet $(2.3 \%)$-air & GB:0.76 Bulk: 0.36 & {$[100]$} \\
\hline $\mathrm{BaZr}_{0.85} \mathrm{Y}_{0.15} \mathrm{O}_{3}$ & 350 & Total: $1.8 \times 10^{-3}$ & Wet $(2.3 \%)-\mathrm{N}_{2}$ & 0.43 & [138] \\
\hline Nano-BaZr $\mathrm{r}_{0.8} \mathrm{Y}_{0.2} \mathrm{O}_{3}$ & 300 & GB: $1.7 \times 10^{-5}$ & Wet $(2.5 \%)-A r$ & 0.79 & {$[101]$} \\
\hline $\mathrm{Ba}_{0.97} \mathrm{Zr}_{0.77} \mathrm{Y}_{0.19} \mathrm{Zn}_{0.04} \mathrm{O}_{3}$ & 300 & Total: $4.8 \times 10^{-5}$ & Wet- $5 \%-\mathrm{Ar}$ & $\mathrm{N} / \mathrm{A}$ & [102] \\
\hline $\mathrm{BaCe}_{0.9} \mathrm{Gd}_{0.1} \mathrm{O}_{3}$ & 300 & Bulk: $3.1 \times 10^{-4} \mathrm{~GB}: 1.1 \times 10^{-6}$ & Wet-Ar & Bulk: 0.53 GB: 0.75 & [103] \\
\hline $\mathrm{BaCe}_{0.8} \mathrm{Zr}_{0.1} \mathrm{Gd}_{0.1} \mathrm{O}_{3}$ & 300 & Bulk: $1.7 \times 10^{-4}$ GB: $8.7 \times 10^{-7}$ & Wet-Ar & Bulk: 0.57 GB: 0.77 & [103] \\
\hline $\mathrm{BaCe}_{045} \mathrm{Zr}_{0.45} \mathrm{Sc}_{0.1} \mathrm{O}_{3}$ & 325 & Total: $2.5 \times 10^{-6}$ & Wet $(5 \%)-\mathrm{H}_{2}-\mathrm{Ar}$ & 0.67 & {$[104]$} \\
\hline $\mathrm{SrCe}_{0.95} \mathrm{Yb}_{0.05} \mathrm{O}_{3}$ & 300 & Total: $2.7 \times 10^{-5}$ & Wet-Ar & Bulk: 0.6 GB: 0.81 & {$[105]$} \\
\hline $\mathrm{Sr}_{3} \mathrm{CaZr}_{0.5} \mathrm{Ta}_{1.5} \mathrm{O}_{8.75}$ & 300 & Total: $5.5 \times 10^{-5}$ & Wet $4 \% \mathrm{H}_{2}-\mathrm{Ar}$ & Bulk: 0.66 GB: 0.85 & [91] \\
\hline $\mathrm{BaCe}_{0.65} \mathrm{Zr}_{0.20} \mathrm{Y}_{0.15} \mathrm{O}_{3-\delta}$ & 300 & Total: $4.4 \times 10^{-4}$ & Wet $5 \% \mathrm{H}_{2}-\mathrm{Ar}$ & Bulk: 0.6 GB: 0.92 & [96] \\
\hline $\mathrm{Ba}_{0.5} \mathrm{Sr}_{0.5} \mathrm{Ce}_{0.6} \mathrm{Zr}_{0.2} \mathrm{Gd}_{0.1} \mathrm{Y}_{0.1} \mathrm{O}_{3-\delta}$ & 300 & Total: $9.5 \times 10^{-4}$ & Wet air & 0.73 & {$[90]$} \\
\hline
\end{tabular}

${ }^{a}$ Bulk conductivity refers to conduction through the grain interior portions of the sample only, where total refers to conduction through both the grain interiors and the grain boundaries

Table 2 Example of proton-conducting oxides with nanometric grain size

\begin{tabular}{|c|c|c|c|c|c|c|}
\hline Materials & Sintering method & $\begin{array}{l}\text { Grain size } \\
(\mathrm{nm})\end{array}$ & $\begin{array}{l}\text { Density } \\
(\%)\end{array}$ & $\begin{array}{l}\text { Pressure } \\
(\mathrm{MPa})\end{array}$ & $\begin{array}{l}\text { Temperature } \\
\left({ }^{\circ} \mathrm{C}\right)\end{array}$ & References \\
\hline $6 \mathrm{~mol} \% \mathrm{Sm}$-doped ceria & HMTA/UV laser irradiation & $2-3$ & N/A & & 50 & {$[33]$} \\
\hline YSZ & RT high-pressure compaction & $<100$ & 86 & 4000 & RT & {$[28]$} \\
\hline $\mathrm{Ce}_{0.9} \mathrm{Gd}_{0.1} \mathrm{O}_{2-\delta}$ & SPS & $\sim 120 \mathrm{~nm}$ & $>97$ & 50 & 1000 & {$[35]$} \\
\hline YSZ & SPS & 50 & $>97$ & $14-141$ & $800-1000$ & [129] \\
\hline $\mathrm{TiO}_{2}$ & HP-FAST & $24-56$ & $92-95$ & $800 \mathrm{MPa}$ & 550 & {$[111]$} \\
\hline $\mathrm{TiO}_{2}$ & Hot pressing & 30 & 90 & 450 & 490 & {$[131]$} \\
\hline $\mathrm{TiO}_{2}$ & Two-stage sintering & 100 & N/A & 0.1 & 750 & [130] \\
\hline $\mathrm{BaTiO}_{3}$ & SPS & 30 & 96 & 100 & 800 & {$[134]$} \\
\hline $\mathrm{BaTiO}_{3}$ & High-pressure-assisted sintering & 30 & 96.2 & 200 & 1000 & [135] \\
\hline
\end{tabular}

The detailed microstructures are shown in Fig. 11

is observed because the strong dependence of water adsorption on temperature. The transition of the conduction mechanism around $50{ }^{\circ} \mathrm{C}$ should be related to the condensation of water at lower temperature.

In zone 3, the conduction of protons can be generally described by the hopping (Grotthuss) mechanism, in which the protons strongly interact with the electron density of nearby electronegative oxygen ions. Proton transport is a thermally activated hopping process requiring the breaking and reforming of the $\mathrm{O}-\mathrm{H}$ bond. Proton conduction by a hopping mechanism shows an important isotope effect which stems from a large difference in the mass of $\mathrm{H}^{+}$and
$\mathrm{D}^{+}$[46-48]. Nowick and Vaysleyb [49] described the theories concerning the isotope effect and resulting impact on proton conduction. The mass difference between hydrogen and deuterium affects their vibrational frequencies in the infrared regime of the compounds [50]. The classical model predicts that the rate of a proton hopping in an oxide is proportional to the attempt frequency or $\mathrm{O}-\mathrm{H} / \mathrm{O}-\mathrm{D}$ vibration frequency. Therefore, the mobility of a proton should be larger than that of a deuteron by factor in the range 1.374-1.414, while the activation energies of the two species should be identical. Miyoshi et al. reported the extent of isotope effect $\left(\sigma\left(\mathrm{H}_{2} \mathrm{O}\right) / \sigma\left(\mathrm{D}_{2} \mathrm{O}\right)\right)$ is around 2 to approximate the theoretical value of 
Figure 3 a Overview of proton transport in nanocrystalline oxide materials: conductivity data for $\mathrm{TiO}_{2}, \mathrm{BaZr}_{0.9} \mathrm{Y}_{0.1} \mathrm{O}_{3}$ [27], and YSZ [28] selected as representative of simple oxides, fluorite-type oxides, and perovskite-type oxides, respectively. b Schematic illustrations showing proton transport via interfacial conduction (zone 1), c proposed proton transport paths in zone 2 , and d proposed transport of the proton in a perovskite-type material in zone 3.

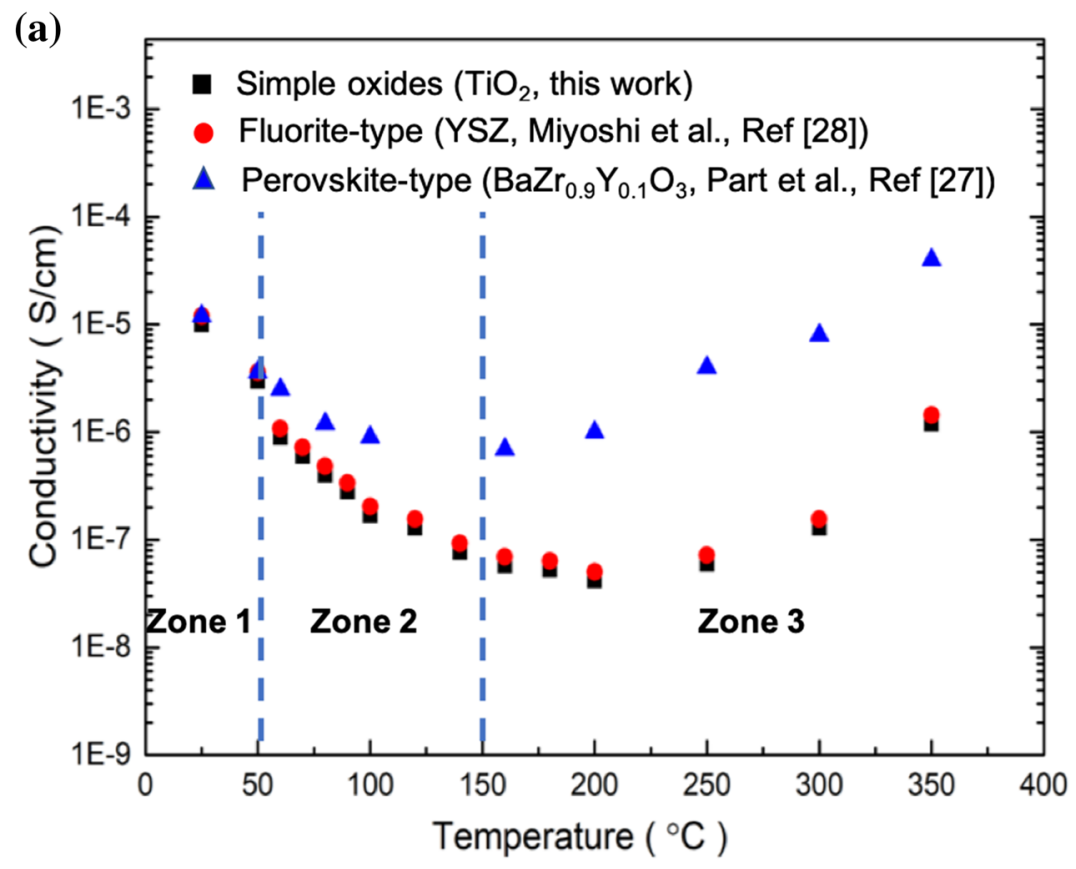

(b)

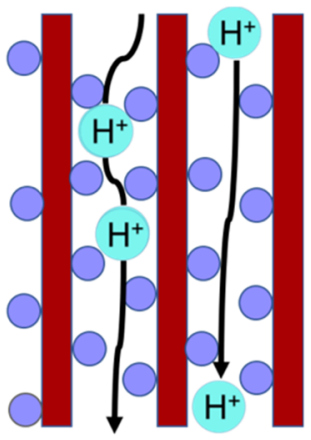

(c)

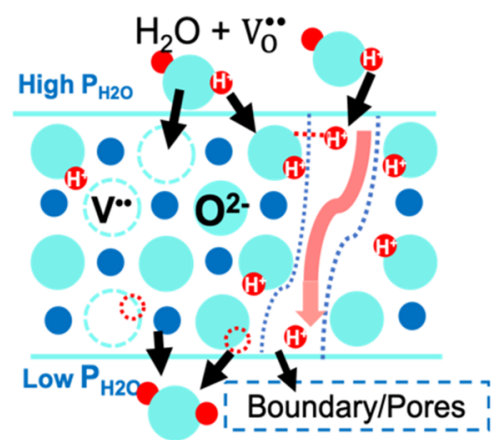

(d)

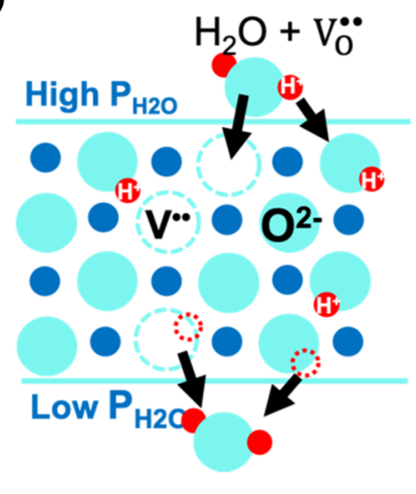

1.4, indicating hopping-type mechanism of proton conduction.

Schematically shown in Fig. $3 c$ is the proposed hopping mechanism of protons, which requires two steps: (1) fast rotation of the protons located on the oxygen ion and (2) proton transfer via hopping toward a neighboring oxygen ion. Proton rotation is associated with a very low activation barrier below $0.1 \mathrm{eV}$ [51], while proton transfer is slower and more difficult. According to the Grotthuss mechanism, the activation energy for proton migration is usually above $0.5 \mathrm{eV}$, indicating that proton jumps between the two adjacent oxygen ions which is the rate-determining step. In zone 3, perovskite-type oxides have the highest conductivity due to the fact that they can simultaneously possess protonic $\left(\mathrm{H}^{+}\right)$and oxygen ionic $\left(\mathrm{O}^{2-}\right)$ conductivity. Moreover, their total conductivities strongly depend on the factors such as temperature, microstructure, oxygen and water vapor partial pressure, and bulk/grain boundary transport. In this temperature range, grain boundary conduction remains a highly resistive mechanism even in nanostructured materials as demonstrated by Park et al. [27] for nanostructured Y-doped $\mathrm{BaZrO}_{3}$.

Protons can be incorporated into the bulk of the perovskite structure as hydroxyl defects $\left(\mathrm{OH}_{\mathrm{O}}\right)$ in the presence of hydrogen and/or water vapor-containing gases. If surrounding the proton conductor with a dry hydrogen atmosphere, the formation of hydroxyl defects occurs through the following reaction: 
$\mathrm{H}_{2}+2 \mathrm{O}_{\mathrm{O}}^{\times} \rightarrow 2 \mathrm{OH}_{\mathrm{O}}+2 \mathrm{e}^{\prime}$,

whereas the most important reaction leading to the formation of hydroxide defects is considered to be the dissociative adsorption of water in humidified atmosphere [52-58]. Proton defects are formed by the dissociative absorption of water at the surface, which requires the presence of oxygen vacancies. Water molecules dissociate into hydroxyl groups $\left(\mathrm{OH}^{-}\right)$and protons $\left(\mathrm{H}^{+}\right)$, with hydroxyl groups incorporated into oxygen vacancies, while the protons form a covalent bond with a lattice oxygen. The reaction can be written in Kröger-Vink notation:

$\mathrm{H}_{2} \mathrm{O}_{(\mathrm{g})}+\mathrm{V}_{\mathrm{O}}^{\ddot{*}}+\mathrm{O}_{\mathrm{O}}^{\times} \rightarrow 2 \mathrm{OH}_{\mathrm{O}}$

The energy of water incorporation into perovskite oxides has been found to be exothermic, and incorporation of water in doped systems is more exothermic than in undoped systems [59]. This is in good agreement with the observation that proton uptake in perovskite material increases with decreasing temperature in the low temperature range [60].

Protonic conductivity abruptly increased at lower $\left(50{ }^{\circ} \mathrm{C}<T<150{ }^{\circ} \mathrm{C}\right.$, zone 2$)$. The hopping mechanism was predominant in this zone. The temperature dependence of the conductivity in this temperature range shows a strong negative activation energy, which can be ascribed to the strong dependence of the amount of absorbed water on temperature [44].

\section{Interfacial conduction mechanism}

Enormous efforts have been devoted to developing a protonic conductor with high proton conductivity. In recent years, nanostructured materials have been employed as a way to enhance the low-temperature proton conductivity [29, 61]. Guo et al. [62] first investigated the water effect on conduction by fabricating a nanocrystalline YSZ film. Anselmi-Tamburini et al. [63] measured the proton conductivity of nanostructured YSZ $(15 \mathrm{~nm})$ which was fabricated using spark plasma sintering at low temperature. A recent study suggested that the protonic transport mechanism in YSZ changes from Grotthuss-type diffusion at high temperatures and low water content to vehicle-type diffusion $\left(\mathrm{H}_{3} \mathrm{O}^{+}\right)$at lower temperature and higher water content [28]. In the low temperature range (zone 1), the differences between the conductivity in simple oxides and the complex materials become negligible. The nanocrystalline materials show a strong hydration (water uptake) behavior in zone 1 , and absorbed water layers on the surface and grain boundary are considered to be the possible path for such a low-temperature proton transport [27]. The transition of the conduction mechanism around $50{ }^{\circ} \mathrm{C}$ should be related to the capillary condensation of water at lower temperature.

Surface termination and structural features are also important in addition to increased overall interfacial area. Taking YSZ as an example, we emphasize that in zone 1, zirconium and oxygen atoms act as Lewis acid and base sites, respectively [64]. The water adsorption calculations show that the (111) surface of YSZ is favorable for the dissociative adsorption of water [65]. Adsorbed water dissociated on the bare surface of the $\mathrm{ZrO}_{2}$-based oxides to form hydroxyl groups on the surface, and the pKa of those hydroxyl groups was found to range between 10 and 13, reported by Tret'yakov et al. [66]. In addition, the enthalpy of the hydroxylation reaction was reported to be rather high, suggesting the instability of the bare surface [67]. These chemical surface features of hydroxyl and $\mathrm{H}_{2} \mathrm{O}$ molecules on the $\mathrm{ZrO}_{2}$-based oxide surface would be expected to facilitate the proton conduction. In contrast to micrometer grains, nanograins tend to involve disordered surface and dangling bonds, which leads to an increased instability of the bare surface and finally gives rise to room-temperature proton conduction of nanograined materials which occurs due to enhanced water absorption and dissociation.

\section{Microstructural effects}

Malavasi et al. pointed out that nanoscale materials exhibit significant size effects due to short diffusion lengths and a high density of interfaces resulting in effective properties of the material dominated by the grain boundary interfaces $[59,68]$. It is generally recognized that proton incorporation into proton conductors (for instance, perovskite oxides) occurs by a two-step process [57, 69-71], and both bulk and grain boundary contribute to the total conductivity. Therefore, the materials microstructure has a significant effect on the electrical properties of these materials. Ionic transport in PCC materials is controlled by the grain boundary phase, which generally acts as a "blocking" layer against ionic transport in polycrystalline materials sintered with micron-size grains. 
However, recent research suggests that the size and structure of the grain boundary can be tailored to affect the behavior of proton transport at interfaces, especially in the low-temperature (LT) regime.

Several authors have called attention to nanoscale materials as a means to design PCCs dominated by grain boundary interfaces. The size effect of nanodomains in these materials can be effectively controlled to fabricate materials with a high density of interfaces but short diffusion lengths, resulting in favorable conduction properties [59, 68]. Indeed, nanostructured materials have been employed as a way to enhance low-temperature proton conductivity [29, 61]. Anselmi-Tamburini et al. [63] measured the proton conductivity of nanostructured YSZ (15 nm) fabricated using spark plasma sintering (SPS) at low temperature. Guo et al. [62] first investigated the water effect on conduction by making a nanocrystalline YSZ film. More recently, Miyoshi et al. have reported notable interfacial protonic conduction in nanostructured YSZ with grain sizes less than $100 \mathrm{~nm}$, which increases dramatically with decreasing grain size. For example, the conductivity increased by three orders of magnitude when reducing the grain size from 100 to $13 \mathrm{~nm}$ at RT. This group suggested a vehicle-type proton transport mechanism in LTs which is proved by disappearance of isotope effect [28].

Haile et al. [72] investigated the influence of grain boundary conductivity and microstructure on the electrical properties of $\mathrm{BaCe}_{0.85} \mathrm{Gd}_{0.15} \mathrm{O}_{3-\delta}$, and the grain size was controlled by sintering at various temperatures (Fig. 4). In this study, 'brick layer model' was used to calculate the grain interior and grain boundary conductivities [73, 74]. Their results indicated that the grain boundaries 22-03-2019 10:10:00 in barium cerate are significantly more resistive than the bulk, and the specific grain boundary conductivity is independent of grain size. Similar result was found by Braun et al. [75]: The activation energy for proton transport in the bulk and grain boundary of $\mathrm{BaZr}_{0.9} \mathrm{Y}_{0.1} \mathrm{O}_{3-\delta}$ was $0.46 \mathrm{eV}$ and $1.21 \mathrm{eV}$, respectively. The origin of the large resistance in grain boundary layer is manifested in the space charge depletion layers near the positively charged grain boundary core [76], where charge transport across the grain boundaries is blocked by depletion of the major charge carriers $\left(\mathrm{H}^{+}, h, V_{O}\right)$ in the space charge zones.
The space charge effect, which is primarily governed by the electrochemical potential of the defect through the grain boundary and grain interior [77], is an inherent material property and shows a strong positive correlation with temperature. Thus, we consider the space charge effect can only have significant effect on the proton conductivity of grain boundaries in zone 3. A space charge effect on grain boundary conduction behavior based on the brick layer model has been suggested and experimentally examined [78]. As a result of this effect, the ionic charge carrier depletes and accumulates in the vicinity (space charge zone) of the grain boundary core. Such a depletion/accumulation of charge carriers is attributed to the existence of excess charge of the grain boundary core, which is inevitably formed due to thermodynamic difference between the grain boundary core and bulk $[79,80]$.

Kim et al. [30] investigated the resistivity of nanoYSZ with different grain sizes (13-100 nm) under water-saturated air. At temperature range higher than $200{ }^{\circ} \mathrm{C}$ (O region), the proton transport was found to be negligible in comparison with oxygen-ion transport, whereas the nano-YSZ becomes a proton conductor below $\sim 120^{\circ} \mathrm{C}$ ( $\mathrm{H}$ region) in water-saturated air (see Fig. 4). More importantly, the total resistance decreases dramatically with decreasing grain size, indicating the leading role of the interface for the determination of proton conduction in nanoYSZ at low temperatures. The grain boundaries in YSZ are recognized to conduct ions selectively, which

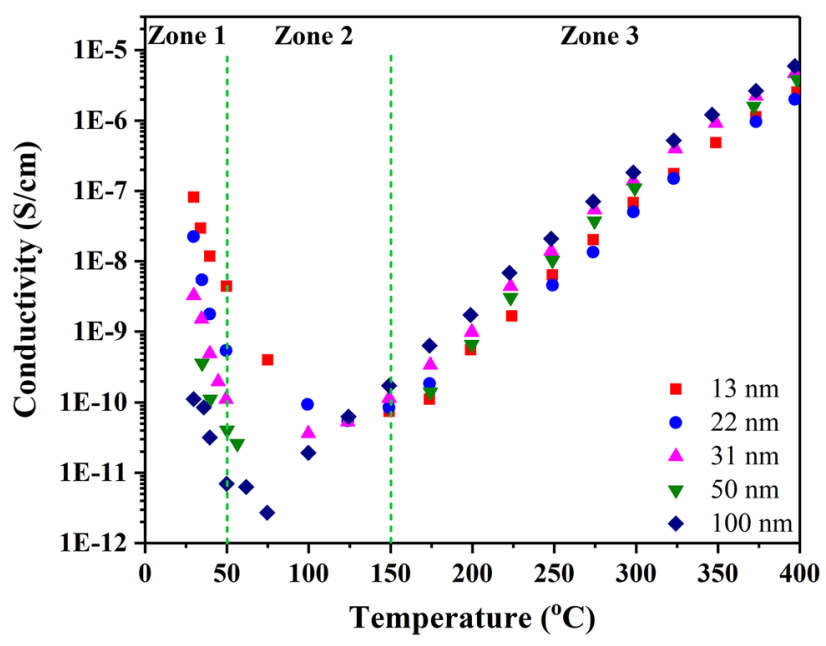

Figure 4 Total conductivity of nano-YSZ with different grain sizes measured under water-saturated air as a function of temperature. Reprinted with permission from Kim et al. [30]. 
may provide conductive paths for proton transport while hindering oxygen-ion transport [81-83]. The same selective nature of grain boundaries was also found in nanocrystalline mixed conducting ceria $[84,85]$.

\section{LT-PCC materials}

\section{Perovskite type}

$\mathrm{BaCeO}_{3}$ was the first perovskite-type oxide found to exhibit proton conduction. Iwahara et al. [69] demonstrated this cubic structured material to be a potential electrolyte material in SOFCs. After more than 20 years of research, the perovskite-type cerates and zirconates have become well-established protonconducting systems [71, 86-88]. The ideally packed perovskite structure is considered simple cubic structure. It has a space group PM-3 m, and the sites corresponding to the $\mathrm{A}$ cation are located at the vertices of the unit cell, B site cation in the center, and oxygen ions at the faces. The $\mathrm{A}$ site is occupied by alkaline earth elements, such as $\mathrm{Sr}, \mathrm{Ba}, \mathrm{Ca}$, while the $\mathrm{B}$ site is occupied by tetravalent elements, e.g., Ce and $\mathrm{Zr}$. Since oxygen vacancy plays an important role in the formation of mobile protons, it is paramount to dope the B site with suitable trivalent elements, such as $\mathrm{Y}, \mathrm{Yb}, \mathrm{Sm}, \mathrm{Nd}, \mathrm{In}, \mathrm{Gd}$.

Figure 5 shows a schematic illustration of a possible proton conduction mechanism in perovskite-type materials which takes place in zone 3. Firstly, protons migrate from oxygen ion I to oxygen ion II (form position 1 to position 2). Then, fast rotational motion of the protons occurs on the oxygen ion II (from 2 to 3). Shown in Fig. 6 are the total conductivities in perovskite-type proton conductors under wet atmosphere as a function of temperature. In zone 3, the proton conduction mechanism occurs by proton hopping between adjacent oxygen ions which was proved by isotope-effect measurements. It is reported that structural distortion and chemical perturbations induced by cation doping can influence the proton conduction [89]. In general, deviation from the ideal cubic perovskite structure mainly leads to a large activation energy.

Pure, undoped $\mathrm{BaCeO}_{3}, \mathrm{SrCeO}_{3}$, and $\mathrm{SrZrO}_{3}$ have limited oxygen vacancy concentrations which leads to low proton incorporation. $\mathrm{BaCeO}_{3}$-based materials exhibit good proton conductivity under a humidified hydrogen-containing atmosphere, but rather poor chemical stability in $\mathrm{CO}_{2}$ atmosphere. Replacement of $\mathrm{Zr}^{4+} / \mathrm{Ce}^{4+}$ with trivalent cations (e.g., $\mathrm{Y}^{3+}$ ) was demonstrated to be a feasible method to increase oxygen vacancy concentration. Singh et al. [90] investigated the chemical stability of $\mathrm{Ba}_{0.5} \mathrm{Sr}_{0.5}$ $\mathrm{Ce}_{1-x-y-z} \mathrm{Zr}_{x} \mathrm{Gd}_{y} \mathrm{Y}_{z} \mathrm{O}_{3-\delta}(0<x<0.5 ; y=0,0.1,0.15$; $z=0.1,0.2$ ) system. Among these materials, $\mathrm{Ba}_{0.5}$ $\mathrm{Sr}_{0.5} \mathrm{Ce}_{0.6} \mathrm{Zr}_{0.2} \mathrm{Gd}_{0.1} \mathrm{Y}_{0.1} \mathrm{O}_{3-\delta}$ (BSCZGY3) had the highest conductivity $9.5 \times 10^{-4} \mathrm{~S} / \mathrm{cm}$ at $300{ }^{\circ} \mathrm{C}$ under wet air $\left(3 \% \mathrm{H}_{2} \mathrm{O}\right)$ atmosphere with an activation energy of $0.73 \mathrm{eV}$. Shuai Wang et al. [18] investigated the electrical properties of $\mathrm{BaCe}_{0.8} \mathrm{Y}_{0.2-x} \mathrm{Nd}_{x} \mathrm{O}_{3-\delta}(x=0,0.05,0.10,0.15)$, which exhibits the highest conductivity when $x=0.05$ (BCYN5). The SEM observation indicates that the densification and grain size of the sintered pellets were significantly enhanced with an increase in $\mathrm{Nd}$ doping concentration. Electrochemical impedance spectra (EIS) demonstrated that both bulk and grain boundary resistances decrease due to the synergistic effect of $\mathrm{Nd}$ and $\mathrm{Y}$ doping at $350{ }^{\circ} \mathrm{C}$.

Conventional perovskite materials only exhibit appreciable levels of proton conduction at high temperature of $500{ }^{\circ} \mathrm{C}$ or above. Recently, newer generation of perovskite compositions has demonstrated impressive conductivity in the LT range. Irvine et al.

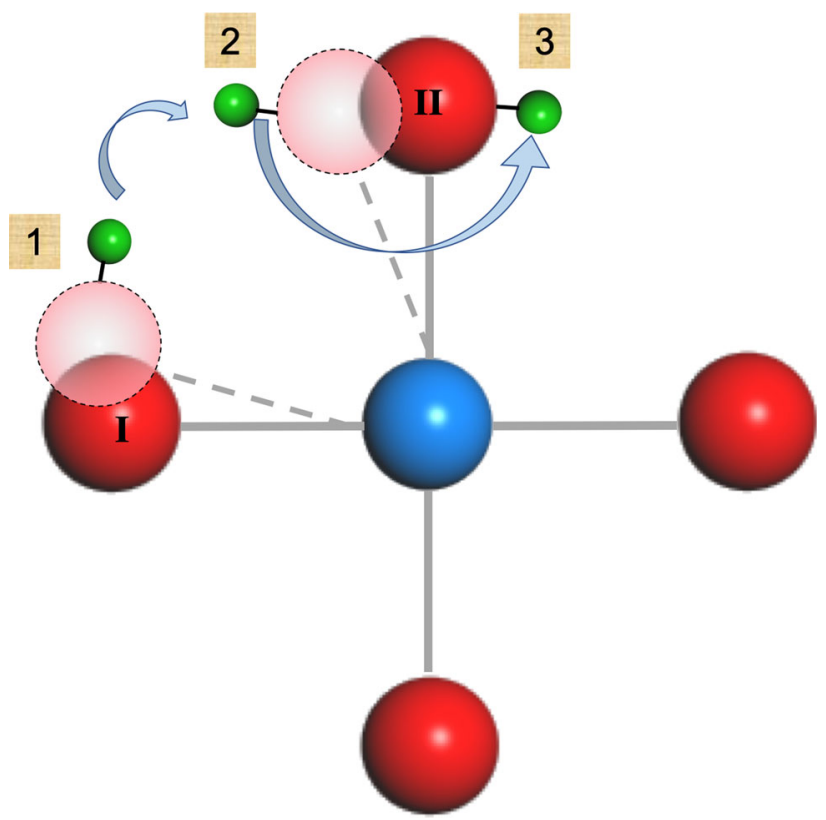

Figure 5 Schematic illustration of possible proton transfer mechanism in perovskite-type materials. Red atoms: oxygen, blue: transition metal, green: protons. 
Figure 6 Total conductivities in perovskite-type proton conductors under wet atmosphere as a function of temperature. $\mathrm{BaZr}_{1-x} \mathrm{In}_{x} \mathrm{O}_{3-\delta}$, $x=0.75$ [92],

$\mathrm{BaZr}_{0.1} \mathrm{Ce}_{0.7} \mathrm{Y}_{0.2} \mathrm{O}_{3-\delta}$ [93],

$\mathrm{BaCe}_{0.9} \mathrm{Y}_{0.1} \mathrm{O}_{2.95}$ [94],

$\mathrm{BaZr}_{0.5} \mathrm{In}_{0.5} \mathrm{O}_{3-\delta}[95]$,

$\mathrm{Sr}_{3} \mathrm{CaZr}_{0.5} \mathrm{Ta}_{1.5} \mathrm{O}_{8.75}$ [91],

$\mathrm{BaCe}_{0.65} \mathrm{Zr}_{0.20} \mathrm{Y}_{0.15} \mathrm{O}_{3-\delta}$ [96],

$\mathrm{BaSn}_{0.5} \mathrm{In}_{0.5} \mathrm{O}_{2.75}$,

$\mathrm{Ba}_{0.9} \mathrm{La}_{0.1} \mathrm{Sn}_{0.5} \mathrm{In}_{0.5} \mathrm{O}_{2.8}$,

$\mathrm{Ba}_{0.9} \mathrm{Gd}_{0.1} \mathrm{Sn}_{0.5} \mathrm{In}_{0.5} \mathrm{O}_{2.8}$ [97].

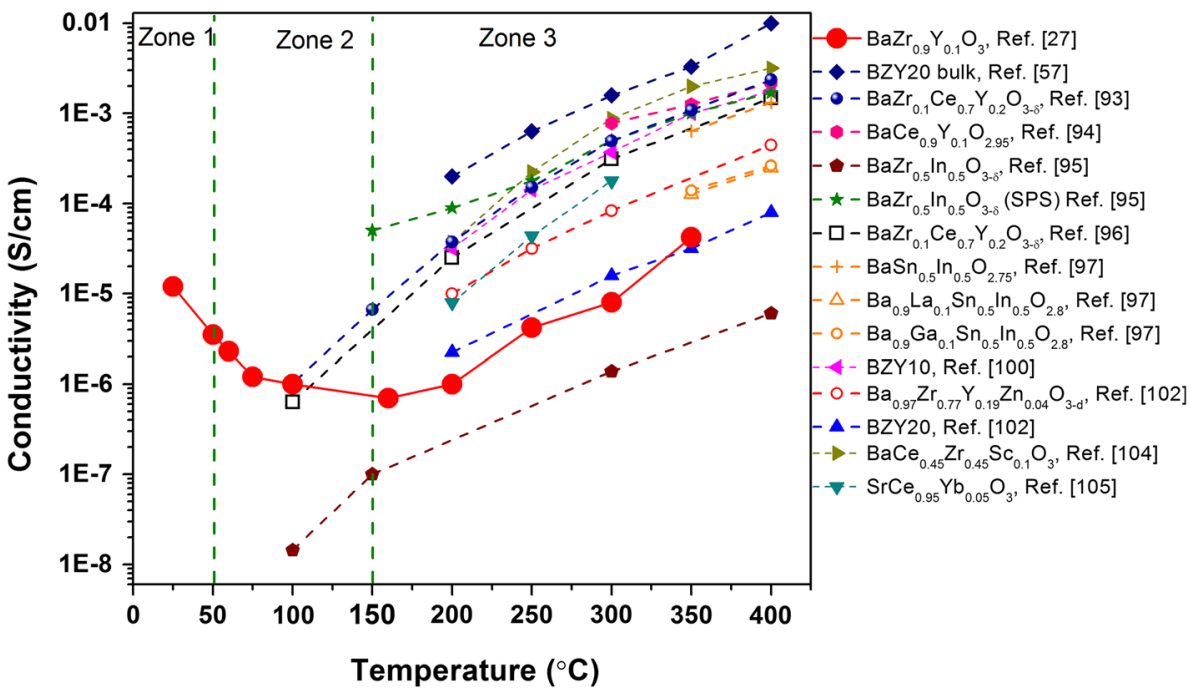

2. At the upper temperature region of the LT regime (zone 3), extending to the IT and HT regimes, the conductivity has additional contributions from oxygen ions due to the decreased water uptake with increasing temperature.

3. Grain boundary conductivity through various mechanisms outlined above dominates the behavior in LT (zones 1, 2, and 3), whereas bulk conductivity is predominant at higher temperatures.

\section{Fluorite-type and simple oxides}

Selected metal oxide hydrates like $\mathrm{ZrO}_{2} \cdot n \mathrm{H}_{2} \mathrm{O}, \mathrm{Sb}_{2}$ $\mathrm{O}_{5} \cdot n \mathrm{H}_{2} \mathrm{O}$ and $\mathrm{WO}_{3} \cdot 2 \mathrm{H}_{2} \mathrm{O}$ have shown considerably high proton conductivity in the $50-150{ }^{\circ} \mathrm{C}$ region $[106,107]$. The possibility of proton conduction in simple oxides $\left(\mathrm{ZrO}_{2}, \mathrm{TiO}_{2}, \mathrm{CeO}_{2}\right)$ at low temperature has been previously investigated. Conventional ceramic ionic conductors rely on bulk ionic transport, whereas a significant increase in the conductivity can be obtained when the grain size of the materials is in the nanometric range [108, 109]. Munir et al. [63] found the ionic conductivity at low temperatures $\left(200{ }^{\circ} \mathrm{C}\right)$ in structurally un-hydrated YSZ only when the grain size of the material is in the nanoscale. Until recently, nanostructured YSZ was used as a lowtemperature protonic conductor. The nanostructured YSZ made use of interfaces such as grain boundaries and surfaces resulting in appreciable proton conductivity at the interfacial hydrated layers [110], while bulk proton conduction in the solid lattice was negligible. 
Figure 7 displays the proton conductivity of fluorite and simple oxides as a function of temperature in wet atmospheres. For fluorite-type YSZ, it was demonstrated that proton conductivity was significantly increased with a decrease in the grain size (from $100 \mathrm{~nm}$ to $10 \mathrm{~nm}$ ) in the LT range (zone 1). Undoped $\mathrm{ZrO}_{2}$ shows a similar behavior in the LT regime. Interestingly, $\mathrm{Y}_{2} \mathrm{O}_{3}$ concentration does not seem to have a significant impact on the protonic conductivity. However, doping of $\mathrm{Y}_{2} \mathrm{O}_{3}$ is known to have an effect on the concentration of oxygen vacancies, crystal structure, and particle morphology which helps determine water absorption and LT proton conduction. Shirpour et al. [25] compared the proton conductivity of microcrystalline $(400 \mathrm{~nm})$ and nanocrystalline $(40 \mathrm{~nm})$ ceria below $200{ }^{\circ} \mathrm{C}$. Their result confirmed the existence of proton conductivity in nanocrystalline ceria at temperatures lower than $200{ }^{\circ} \mathrm{C}$. Nanocrystalline samples exhibit more than eight orders of magnitude enhancement of total conductivity in wet atmosphere, which suggested unique properties of grain boundaries in such nanostructured materials.

Sun et al. [112] developed $\mathrm{La}_{2} \mathrm{Ce}_{2} \mathrm{O}_{7}$ (LDC) with cubic fluorite crystal structure as a promising proton conductor. As shown in Fig. 7, the total conductivity of LDC is $4.5 \times 10^{-5}$ at $250{ }^{\circ} \mathrm{C}$ in $3 \% \mathrm{H}_{2} \mathrm{O}$-humidified air. Sun's work clearly showed that the environmental humidity could significantly affect the total conductivity of LDC, which could increase dramatically with increasing humidity. In addition, a proton transport number defined as the ratio of proton ionic conductivity to the total measured conductivity was measured to be approximately 0.89 at $250{ }^{\circ} \mathrm{C}$ in $3 \%$ $\mathrm{H}_{2} \mathrm{O}$-humidified air, indicating the proton transfer process played the dominant role under high water vapor pressure and low temperature [113]. Since protons are the main charge carriers at temperatures below $450{ }^{\circ} \mathrm{C}$ as demonstrated by Norby et al. [114, 115], LDC would be a promising proton conductor in the applications outlined in this review.

\section{Brownmillerite type}

Brownmillerite is a rare oxide mineral with chemical formula $\mathrm{Ca}_{2}(\mathrm{Al}, \mathrm{Fe})_{2} \mathrm{O}_{5}$. $\mathrm{Ba}_{2} \mathrm{In}_{2} \mathrm{O}_{5}$ is a well-known oxide ion and proton-conductive material. Hui et al. reported the electrical conductivity of ceria-doped $\mathrm{Ba}_{2} \mathrm{In}_{2} \mathrm{O}_{5}$ was significantly affected by the presence of hydrogen in the temperature range of $100-300{ }^{\circ} \mathrm{C}$. As shown in Fig. 8, the electrical conductivity was as high as $7 \times 10^{-3} \mathrm{~S} / \mathrm{cm}$ at $300{ }^{\circ} \mathrm{C}$ in an atmosphere of $50 \%$ hydrogen [116]. When BIS was applied as electrolyte materials with hydrogen as fuel, an open circuit voltage of $0.87 \mathrm{~V}$ was attained and was stable during an operation period of $60 \mathrm{~h}$ at $280{ }^{\circ} \mathrm{C}$. The proton transfer numbers were measured to be around 0.86 at $100{ }^{\circ} \mathrm{C}$, indicating $\mathrm{BIC}$ is a mixed electronic and ionic conductor. Due to the mixed electronic nature of conduction, these materials are promising candidates for use as electrodes in SOFCs.

\section{Phosphate type}

Low-temperature conduction in phosphate materials requires the presence of substantial amount of water enabling a vehicle transport mechanism. At high temperature, water should be removed from the structure and proton conduction can be attributed to a Grotthuss-type mechanism where proton hopping along $\mathrm{P}-\mathrm{O}-\mathrm{H}$ bonds occurs $[117,118]$. Haile et al. demonstrated phosphate-type materials based on $\mathrm{CsHSO}_{4}$ as fuel cell electrolytes with excellent performance [119-124]. Chen et al. [125] reported a proton and oxide co-ion conductor, $\mathrm{Sn}_{0.9} \mathrm{In}_{0.1} \mathrm{P}_{2} \mathrm{O}_{7}$. The maximum protonic conductivities of $\mathrm{Sn}_{0.9} \mathrm{In}_{0.1}$ $\mathrm{P}_{2} \mathrm{O}_{7}$ achieved are $0.019 \mathrm{~S} / \mathrm{cm}$ around $200{ }^{\circ} \mathrm{C}$ in $40 \%$ $\mathrm{H}_{2} \mathrm{O}$. The electrochemical properties of proton-conductive $\mathrm{CsH}_{2} \mathrm{PO}_{4} / \mathrm{SiP}_{2} \mathrm{O}_{7}$ composite were synthesized and investigated in the temperature range of $110-287^{\circ} \mathrm{C}$, and the maximum conductivity reached $44 \mathrm{mS} / \mathrm{cm}$ at $266^{\circ} \mathrm{C}$ [124]. Figure 9 shows the conductivity of a $\mathrm{SnP}_{2} \mathrm{O}_{7}-\mathrm{SnO}_{2}$ composite. The conductivity increases with temperature and in wet atmosphere is higher than the level exhibited in dry atmospheres. An H/D isotope effect was observed for $\mathrm{SnP}_{2} \mathrm{O}_{7}$ which suggested that proton conduction in this material was based on a proton-hopping mechanism.

\section{Other types}

Although research into proton-conducting ceramics began more recently than oxide-ion conductors, several proton conductors described above have been identified that exhibit sufficient proton conductivity for us as electrolytes of PCFCs. In this section, we describe some new material systems that have been studied in the search for low-temperature proton conduction. 
Figure 7 Proton conductivity of fluorite and simple oxides as a function of temperature in wet atmosphere. The solid line indicated extrapolation of the oxygen-ion conductivity of the $50 \mathrm{~nm}$ YSZ sample [34]. YSZ [24], CGO [35], undoped-ceria [25], $\mathrm{TiO}_{2}$ [111], SDC and YSZ [61], $\mathrm{La}_{2} \mathrm{Ce}_{2} \mathrm{O}_{7}$ [112].

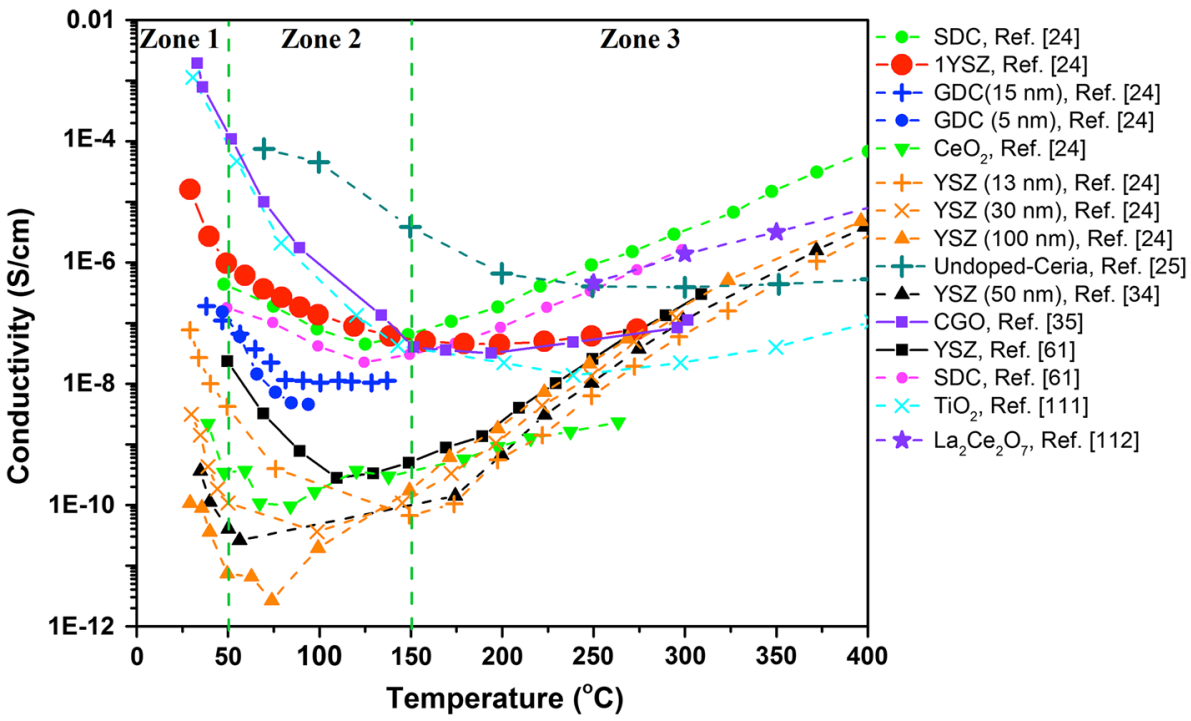

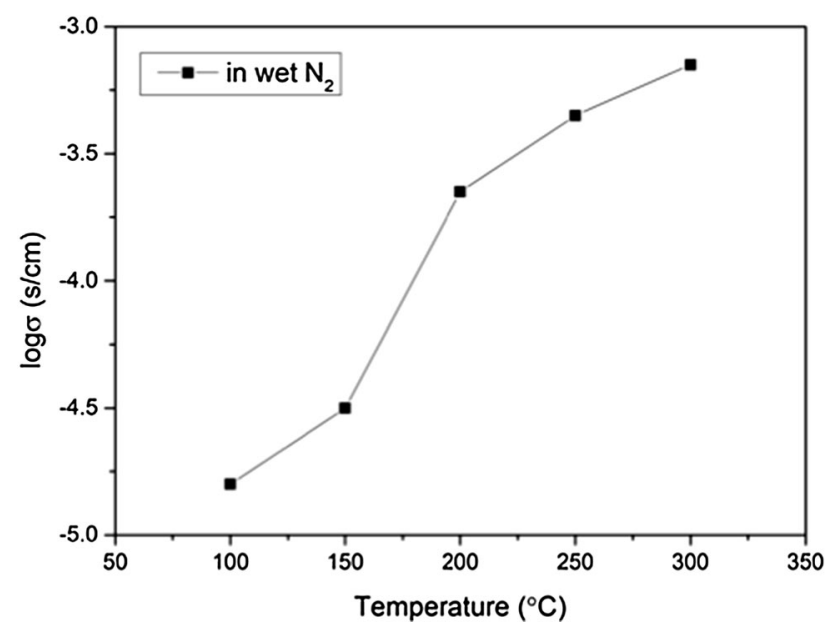

Figure 8 Proton conductivity of brownmillerite-type oxides ceria-doped $\mathrm{Ba}_{2} \mathrm{In}_{2} \mathrm{O}_{5}$ as a function of temperature in wet atmosphere. Reprinted with permission from Hui et al. [116].

Aoki et al. [127] reported the proton conductivity of amorphous $\mathrm{Al}_{n} \mathrm{Si}_{1-n} \mathrm{O}_{x}$ thin film which has the heterogeneous nanoscale microstructure comprised of the ion-conducting, condensed glass microdomain and a poorly conductive, uncondensed glass microdomain. The proton conductivity reached $1.1 \times 10^{-5} \mathrm{~S} / \mathrm{cm}$ when the thickness was less than $5 \mathrm{~nm}$ at $250{ }^{\circ} \mathrm{C}$. Dion-Jacobson (D-J)-type layered perovskite $\left(\mathrm{ACa}_{2} \mathrm{Nb}_{3} \mathrm{O}_{10}\right)$ oxides were developed by Sakthivel et al. as hydrogen gas sensors at a working temperature of $45^{\circ} \mathrm{C}$. The proton conductivity of $\mathrm{KCa}_{2} \mathrm{Nb}_{3} \mathrm{O}_{10} \quad\left(6.3 \times 10^{-5} \mathrm{~S} / \mathrm{cm}\right.$ at $\left.45^{\circ} \mathrm{C}\right)$ was observed to be higher than analogs with $\mathrm{Rb}$ or $\mathrm{Cs}$ substituted on the A site. Kojo et al. [128] investigated the influence of the $\mathrm{La} / \mathrm{W}$ ratio on the electronic conductivity of lanthanum tungstate. When $\mathrm{La} /$ $W=6.5$, the conductivity was $9.0 \times 10^{-5} \mathrm{~S} / \mathrm{cm}$ at $300{ }^{\circ} \mathrm{C}$ under wet Ar. Details of the temperature dependence over that LT regime defined in this review have not yet been reported.

\section{Processing of nanocrystalline proton conductors}

On the basis of the results described above, proton conduction occurs in polycrystalline samples with predominately nanometric-sized grains. One of the approaches to develop new low-temperature ionic

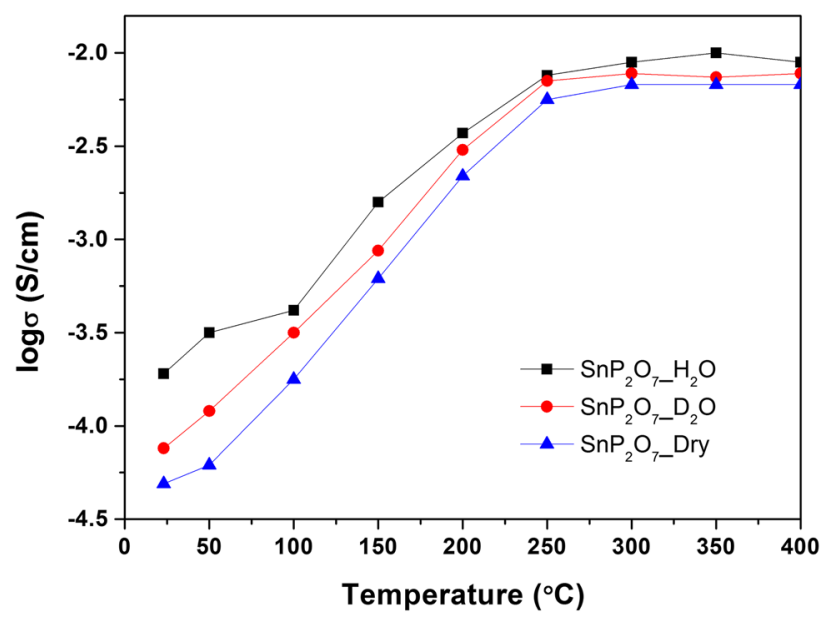

Figure 9 Temperature dependence of the conductivity of the $\mathrm{SnP}_{2} \mathrm{O}_{7}-\mathrm{SnO}_{2}$ composite ceramic in various atmospheres [120], $\mathrm{CeP}_{2} \mathrm{O}_{7}$ [126]. 
conductors would be to increase the number of available interfaces such as grain boundaries and select surfaces that are favorable for hydration. Here, we will review several techniques which are available to process proton-conducting ceramics with the requisite grain sizes below $50 \mathrm{~nm}$.

\section{RT high-pressure compaction}

Several nonconventional sintering approaches have been developed to fabricate nanostructured protonic ceramics. Miyoshi et al. fabricated nanograined YSZ through a combination of low-temperature nanopower synthesis and room-temperature high-pressure (4 GPa) compaction [24, 64]. The as-obtained samples after high-pressure compaction have grain size being typically smaller than $100 \mathrm{~nm}$ and have relatively good mechanical strength for handling and cutting. The relative density can reach $86 \%$ with limited nanopores. Those nanograined specimens essentially include interfacial hydrated layers between grains (Fig. 10), which were regarded to facilitate incorporation of $\mathrm{H}_{2} \mathrm{O}$ molecules.

\section{Hexamethylenetetramine (HMTA) or ultraviolet (UV) laser irradiation method}

Takamura et al. successfully prepared single nanosized $6 \mathrm{~mol} \% \mathrm{Sm}$-doped ceria with a grain size of approximately 2 to $3 \mathrm{~nm}$ by using hexamethylenetetramine (HMTA) or ultraviolet (UV) laser irradiation method, with water adsorption of 3 mass $\%$ and 0.12 mass $\%$, respectively [33]. As a result, the proton conductivity of as-obtained dense nanocrystalline ceria was about $10^{-7}$ to $10^{-8} \mathrm{~S} / \mathrm{cm}$ at around $50{ }^{\circ} \mathrm{C}$ under humidified atmosphere (Fig. 11).

\section{Hot pressing}

A hot pressing method was applied by Weibel et al. [131] to prepare nanocrystalline $\mathrm{TiO}_{2}$ ceramics. A density higher than $90 \%$ of the theoretical limit with a mean grain size of $30 \mathrm{~nm}$ was obtained at temperatures as low as $490{ }^{\circ} \mathrm{C}$ under $0.45 \mathrm{GPa}$ for $2 \mathrm{~h}$. Mazaheri et al. [130] adopted two-stage sintering to obtain titania nanograins assisted by the anatase-torutile phase transformation. At the end of the first sintering step, the minimum grain size was around $250 \mathrm{~nm}$ with a nearly complete anatase-to-rutile transformation (98\% rutile). However, at the end of the second step, the anatase-to-rutile transformation facilitated a reduction in grain size to $\sim 100 \mathrm{~nm}$. Even though the grain size was slightly larger than other sintering approaches, the two-step sintering features densification at a lower temperature without the application of external pressure.

\section{Spark plasma sintering (SPS)}

The SPS technique is similar to traditional hot pressing, but in SPS the sample is heated by a highintensity and low-voltage pulsed DC current flowing through the sample and graphite die resulting in rapid heating [132]. The heating rate of SPS may be as fast as $100{ }^{\circ} \mathrm{C} / \mathrm{min}$, enabling rapid densification at very low temperatures with very short sintering times. Pérez-Coll et al. prepared dense nanocrystalline $\mathrm{Ce}_{0.9} \mathrm{Gd}_{0.1} \mathrm{O}_{2-\delta}(\mathrm{CGO})$ with a grain size of $\sim$ $120 \mathrm{~nm}$ by spark plasma sintering (SPS) of nanoscale powders [35]. Their result found that the large volume of grain boundaries in the nanometric materials are highly blocking oxygen ions but can promote proton transport through surface effects. The roomtemperature proton conductivity of nanostructured $\mathrm{Ce}_{0.9} \mathrm{Gd}_{0.1} \mathrm{O}_{2-\delta}$ is $4-5$ times greater than that of micrometric samples. This group also prepared dense nanocrystalline YSZ with a grain size of $\sim 50 \mathrm{~nm}$ and a density $>97 \%$ of the theoretical value by SPS [129]. Although samples prepared at relatively low pressures require high sintering temperature (800-1000 $\left.{ }^{\circ} \mathrm{C}\right)$, SPS has been a proven method to successfully fabricate samples with nanoscale grain features. Hinterberg et al. [133] reported a spark-

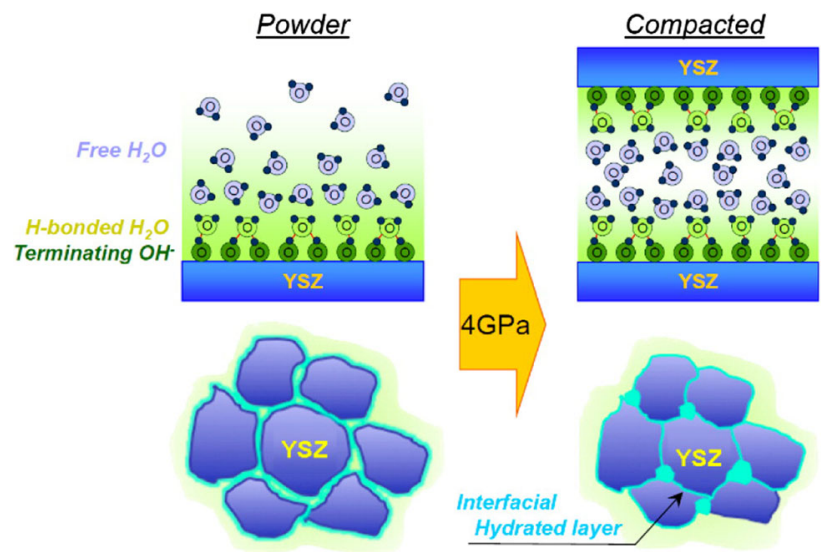

Figure 10 Schematic of the protonic species on nano grain surface (upper) and ultra-high-pressure compaction of nano grain (lower). Reprinted with permission from Miyoshi et al. [24]. 
Figure 11 SEM micrographs of the fractured surface of $8 \mathrm{~mol} \% \mathrm{Y}_{2} \mathrm{O}_{3}-\mathrm{ZrO}_{2}$ (YSZ) by spark plasma sintering (a). 1YSZ specimen by roomtemperature high-pressure (4 GPa) compaction (b). $\mathrm{TiO}_{2}$ sample by two-step sintering process (c). On behalf of Acta Materialia Inc. anatase sample sintered at $550{ }^{\circ} \mathrm{C}$ by highpressure field-assisted sintering (d). Phase-pure anatase by hot pressing (e) Reprinted with permission from Tandé et al. [129] (a), Miyoshi et al. [24] (b), Mazaheri et al. [130] (c), Maglia et al. [111] (d), Weibel et al. [131] (e).
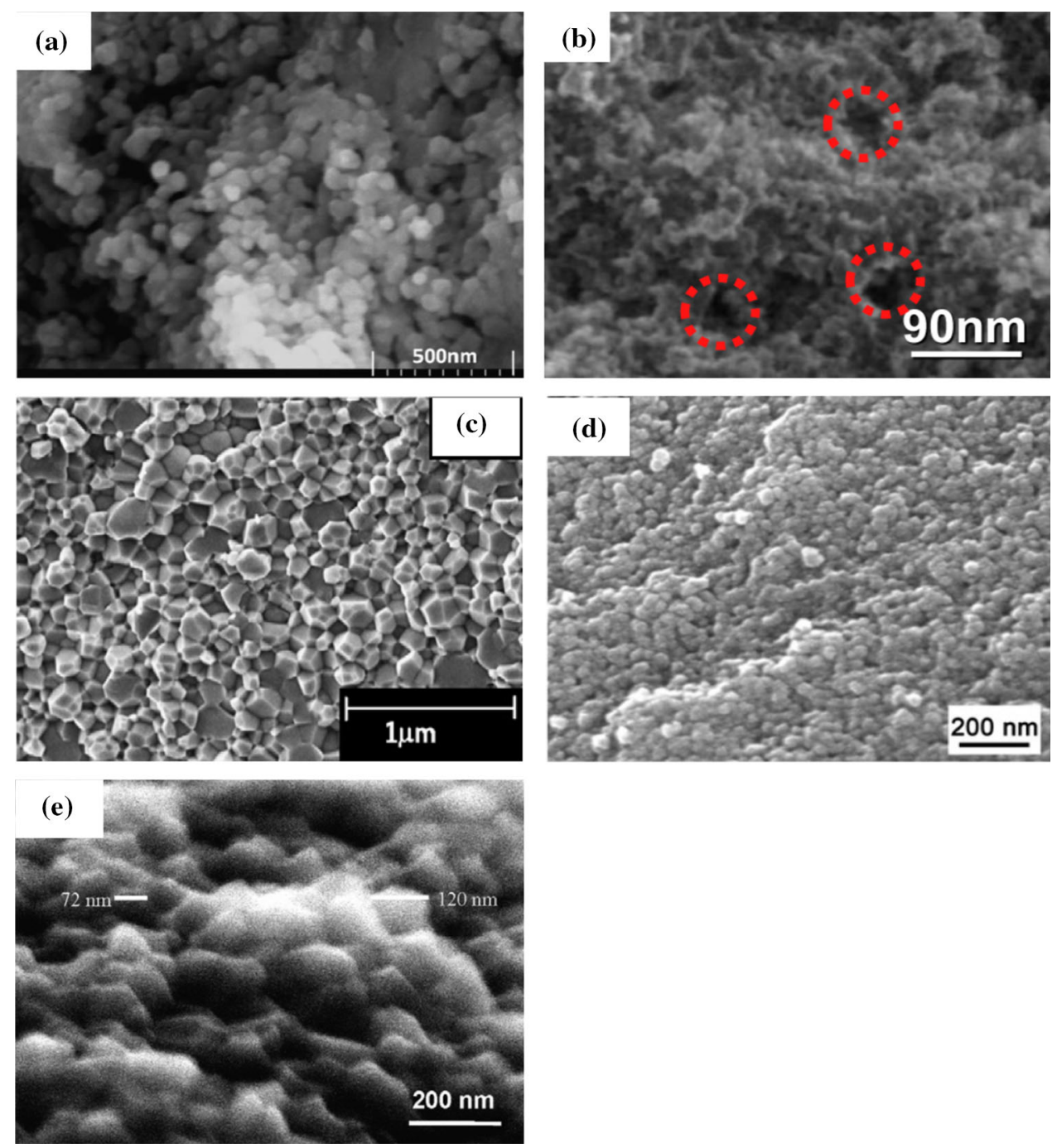

plasma-sintered nanograined YSZ with a grain size (ca. $30 \mathrm{~nm}$ ) and a relative density of $95.8 \%$ and higher. Spark-plasma-sintered YSZ with a grain size of $16 \mathrm{~nm}$ and relative density above $98 \%$ was reported by Chiodelli et al. [29] The high density of protonconducting ceramics prepared by the SPS technique enables materials to be used as gas separation membranes and electrolyte materials at low temperature.

\section{High-pressure field-assisted sintering method (HP-FAST)}

Maglia et al. [111] prepared the high-density bulk anatase samples with a grain size ranging between 24 and $56 \mathrm{~nm}$ by high-pressure field-assisted sintering method (HP-FAST) which is operated at $550{ }^{\circ} \mathrm{C}$ under a pressure of $800 \mathrm{MPa}$. The sintered sample appears to be free of residual inter-agglomerate porosity or cracks and has a good homogeneity of the grain-size distribution with limited presences of approximately $6 \mathrm{vol} \%$ nanopores.

\section{LT-PCCs Applications}

\section{Proton exchange membranes}

Recent research conducted by Sgabanikia et al. [136] showed that the introduction of nanosized a $\mathrm{La}_{2} \mathrm{Ce}_{2}$ $\mathrm{O}_{7}$ into polybenzimidazole (PBI) membrane could increase the hydrophilicity of the polymer and modify the hydrophilic/hydrophobic properties of $\mathrm{PLC}_{x}$ ( $\mathrm{PBI} / \mathrm{La}_{2} \mathrm{Ce}_{2} \mathrm{O}_{7}$ nanocomposite membranes). $\mathrm{La}_{2} \mathrm{Ce}_{2} \mathrm{O}_{7}$ can enhance the proton conductivity and the ion exchange capacity in the LT regime due to the 
introduction of the LDC which provides additional hopping paths for proton transport.

\section{Proton-conducting fuel cells}

Kim et al. [31] showed the feasibility of power generation at room temperature using water concentration cells with nanoscale fluorite-structured oxides as electrolytes. They prepared dense, bulk nanostructured YSZ (8 mol\% yttria) and SDC (20 mol\% samaria) with a grain size of $\sim 15 \mathrm{~nm}$ by field-activated sintering method. As shown in Fig. 12, a water concentration cell was constructed using the nanostructured YSZ and SDC as electrolytes. When one side of the cell was immersed into pure water and the other side was exposed to wet air, the emf reached about $+110 \mathrm{mV}$ and about $+220 \mathrm{mV}$ for the YSZ and SDC cells, respectively. In short circuit condition, a steady-state current of $6 \mathrm{nA}$ was detected for SDC cell. Interestingly, the currents were three orders of magnitude lower for the microstructured YSZ and SDC electrolytes, indicating the essential role of interfacial proton transport.

\section{Sensors}

Sakthivel et al. [137] proposed a D-J-type proton conductor $\mathrm{KCa}_{2} \mathrm{Nb}_{3} \mathrm{O}_{10}$ as hydrogen sensor. Deposition of $\mathrm{Pt}$ electrode on the top of the proton conductor was performed using the multistep impregnationreduction method. A linear response current was observed at a hydrogen concentration of up to $5 \%$ and the same in the low ppm range (50-1000 ppm). A response time between 3 and $18 \mathrm{~s}$ was observed for $\mathrm{H}_{2}$ concentration change in the range $1-7 \%$ at the temperature of $45{ }^{\circ} \mathrm{C}$. This result indicates the possibility of development of a stable solid electrolytebased sensor with excellent sensitivity and fast response time.

\section{Perspective}

Low-temperature proton conduction (LT-PCCs), defined as operating in the temperature range of $25-400{ }^{\circ} \mathrm{C}$ was shown to depend on the material structure, temperature-dependent proton-conducting mechanisms, and microstructure indicating that interfacial protonic conduction dominates in the LT regime. Three temperature zones each possessed interfacial conduction through different mechanisms. Zone 1, the lowest temperature region, was dominated by water absorption, dissociation, and a vehicle transport mechanism. Zone 2 extending from 50 to $150{ }^{\circ} \mathrm{C}$ was characterized by a transition from free water to bound water in the form of hydroxyl $\mathrm{OH}$ groups that experienced hopping mechanism at the interface. Zone 3 extending from 150 to above $400{ }^{\circ} \mathrm{C}$ was characterized by bulk incorporation and diffusion through hopping mechanism (Grotthuss) structures. From a materials perspective, essentially all the known materials exhibit the same qualitative trends in conductivity in zone 1 and zone 2 since water is known to absorb to a wide range of ceramic surfaces with an increased driving force with large surface areas inherent to nanostructured materials. However, zone 3 exhibits distinctly different behavior as a function of materials class since proton conduction is determined by incorporation and mobility of protonic species in the crystalline lattice. Perovskites incorporate protonic defects in wet atmospheres through oxygen vacancy sites, as compared to simple oxides such as $\mathrm{TiO}_{2}$ which do not exhibit the capacity for bulk proton incorporation. Conductivities in zone 3 for simple oxides are related to electronic contributions to conductivity and contributions from oxygen ions as the temperature increases.

This review points to the importance of tailoring the surface chemical property and the potential doping strategies with alkaline earth metal ions to enhance the water absorption and proton mobility. Additional data are required for a wide range of materials in the LT regime, especially in zone 1 and zone 2 where water absorption and dissociation on surfaces are dominant. Computational studies focused on surface-dependent dissociative adsorption of water, and subsequent temperature-dependent transport would aid in materials discovery.

Finally, in addition to the role of hydrogen isotopes in evaluating the transport mechanism based on mass effects outlined earlier, hydrogen isotope transport in the LT regime may play an important role in capturing and processing of hydrogen isotopes. The lowtemperature water adsorption properties of nanoscale structured ceramics outlined in this review could provide a low-cost and transformative avenue to address tritium management challenges. Enhanced understanding of LT proton transport materials and mechanisms would equivalently benefit energy conversion and storage applications based on solid oxide 
Figure 12 Photograph and a schematic diagram of a water concentration cell operation at room temperature. Reprinted with permission from Kim et al. [31].

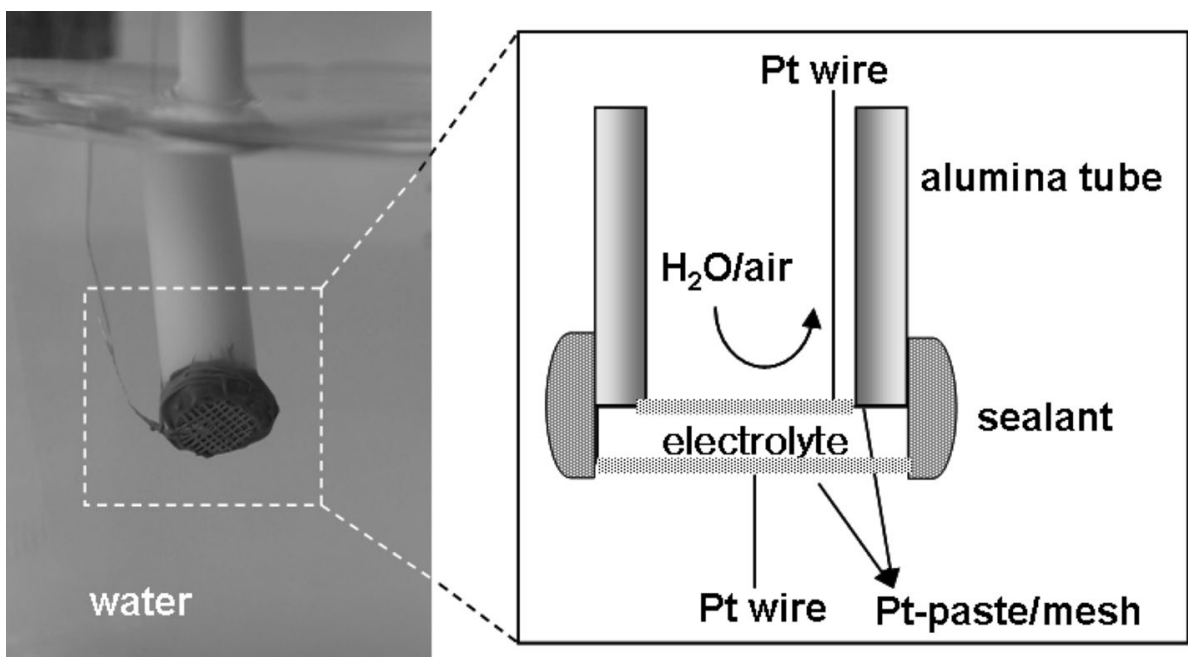

fuel cells, separation membranes, and associated sensors.

\section{Acknowledgements}

The authors gratefully acknowledge the Award DENE0008703 from the Department of Energy, Nuclear Energy Research Programs (DOE-NEUP) for Project CFA-17-12798: Nanostructured Ceramic Membranes for Enhanced Tritium Management.

Open Access This article is distributed under the terms of the Creative Commons Attribution 4.0 International License (http://creativecommons.org/ licenses/by/4.0/), which permits unrestricted use, distribution, and reproduction in any medium, provided you give appropriate credit to the original author(s) and the source, provide a link to the Creative Commons license, and indicate if changes were made.

\section{References}

[1] Fabbri E, Pergolesi D, Traversa E (2010) Materials challenges toward proton-conducting oxide fuel cells: a critical review. Chem Soc Rev 39:4355-4369. https://doi.org/10. 1039/b902343g

[2] Bi L, Da'as EH, Shafi SP (2017) Proton-conducting solid oxide fuel cell (SOFC) with Y-doped $\mathrm{BaZrO}_{3}$ electrolyte. Electrochem Commun 80:20-23. https://doi.org/10.1016/j. elecom.2017.05.006

[3] Shi Z, Sun W, Wang Z et al (2014) Samarium and Yttrium Codoped $\mathrm{BaCeO}_{3}$ proton conductor with improved sinterability and higher electrical conductivity. ACS Appl Mater Interfaces 6:5175-5182. https://doi.org/10.1021/a m500467m

[4] Wang S, Shen J, Zhu Z et al (2018) Further optimization of barium cerate properties via co-doping strategy for potential application as proton-conducting solid oxide fuel cell electrolyte. J Power Sour 387:24-32. https://doi.org/10.10 16/j.jpowsour.2018.03.054

[5] Hou J, Miao L, Hui J et al (2018) A novel in situ diffusion strategy to fabricate high performance cathode for low temperature proton-conducting solid oxide fuel cells. J Mater Chem A 6:10411-10420. https://doi.org/10.1039/ C8TA00859K

[6] Clark D, Tong J, Morrissey A et al (2014) Anomalous lowtemperature proton conductivity enhancement in a novel protonic nanocomposite. Phys Chem Chem Phys 16:5076-5080. https://doi.org/10.1039/C4CP00468J

[7] Xu X, Bi L, Zhao XS (2018) Highly-conductive protonconducting electrolyte membranes with a low sintering temperature for solid oxide fuel cells. J Membr Sci 558:17-25. https://doi.org/10.1016/j.memsci.2018.04.037

[8] Wang B, Liu X, Bi L, Zhao XS (2019) Fabrication of highperformance proton-conducting electrolytes from microwave prepared ultrafine powders for solid oxide fuel cells. J Power Sour 412:664-669. https://doi.org/10.1016/j.jpow sour.2018.11.051

[9] Xu N, Zhang C, Huang K (2018) Proton-mediated energy storage in intermediate-temperature solid-oxide metal-air batteries. J Mater Chem A 6:20659-20662. https://doi.org/ 10.1039/C8TA08180H

[10] Hübert T, Boon-Brett L, Black G, Banach U (2011) Hydrogen sensors: a review. Sens Actuators B Chem 157:329-352. https://doi.org/10.1016/j.snb.2011.04.070 
[11] Tao Z, Yan L, Qiao J et al (2015) A review of advanced proton-conducting materials for hydrogen separation. Prog Mater Sci 74:1-50. https://doi.org/10.1016/j.pmatsci.2015. 04.002

[12] Kura C, Kunisada Y, Tsuji E et al (2017) Hydrogen separation by nanocrystalline titanium nitride membranes with high hydride ion conductivity. Nat Energy 2:786-794. h ttps://doi.org/10.1038/s41560-017-0002-2

[13] Wang H, Wang X, Meng B et al (2018) Perovskite-based mixed protonic-electronic conducting membranes for hydrogen separation: recent status and advances. J Ind Eng Chem 60:297-306. https://doi.org/10.1016/j.jiec.2017.11. 016

[14] Fang S, Wang S, Brinkman KS, Chen F (2014) A sinteractive $\mathrm{Ni}-\mathrm{BaZr}_{0.8} \mathrm{Y}_{0.2} \mathrm{O}_{3-\delta}$ composite membrane for hydrogen separation. J Mater Chem A 2:5825-5833. http s://doi.org/10.1039/c3ta14777k

[15] Liu M, Sun W, Li X et al (2013) High-performance Ni$\mathrm{BaZr}_{0.1} \mathrm{Ce}_{0.7} \mathrm{Y}_{0.1} \mathrm{Yb}_{0.1} \mathrm{O}_{3-\delta} \quad(\mathrm{BZCYYb})$ membranes for hydrogen separation. Int $\mathrm{J}$ Hydrogen Energy 38:14743-14749. https://doi.org/10.1016/j.ijhydene.2013.0 9.057

[16] Mukundan R (1999) Tritium conductivity and isotope effect in proton-conducting perovskites. J Electrochem Soc 146:2184-2187. https://doi.org/10.1149/1.1391911

[17] Steele BCH, Heinzel A (2010) Materials for fuel-cell technologies. Nature 414:345-352

[18] Wang S, Shen J, Zhu Z et al (2018) Further optimization of barium cerate properties via co-doping strategy for potential application as proton-conducting solid oxide fuel cell electrolyte. J Power Sour 387:24-32. https://doi.org/10.10 16/j.jpowsour.2018.03.054

[19] Zhu Z, Liu B, Shen J et al (2016) $\mathrm{La}_{2} \mathrm{Ce}_{2} \mathrm{O}_{7}$ : a promising proton ceramic conductor in hydrogen economy. J Alloy Compd 659:232-239. https://doi.org/10.1016/j.jallcom.20 15.11 .041

[20] Zhang Y, Knibbe R, Sunarso J et al (2017) Recent progress on advanced materials for solid-oxide fuel cells operating below $500{ }^{\circ} \mathrm{C}$. Adv Mater 29:1700132-1700164. https://d oi.org/10.1002/adma.201700132

[21] Marrony M (2016) Proton-conducting ceramics. CRC Press, Baco Raton

[22] Kochetova N, Animitsa I, Medvedev D et al (2016) Recent activity in the development of proton-conducting oxides for high-temperature applications. RSC Adv 6:73222-73268. h ttps://doi.org/10.1039/C6RA13347A

[23] Wachsman ED, Lee KT (2011) Lowering the temperature of solid oxide fuel cells. Science 334:935-939. https://doi. org/10.1126/science. 1204090
[24] Miyoshi S, Akao Y, Kuwata N et al (2014) Low-temperature protonic conduction based on surface protonics: an example of nanostructured yttria-doped zirconia. Chem Mater 26:5194-5200. https://doi.org/10.1021/cm5012923

[25] Shirpour M, Gregori G, Merkle R, Maier J (2011) On the proton conductivity in pure and gadolinium doped nanocrystalline cerium oxide. Phys Chem Chem Phys 13:937-940. https://doi.org/10.1039/C0CP01702G

[26] Chiang Y-M, Lavik EB, Kosacki I et al (1996) Defect and transport properties of nanocrystalline $\mathrm{CeO}_{2-\mathrm{x}}$. Appl Phys Lett 69:185-187. https://doi.org/10.1063/1.117366

[27] Park HJ, Roh JW (2016) Protonic conduction of nanostructured Y-Doped BaZrO 3. J Nanomater 2016:1-6. http s://doi.org/10.1155/2016/8757305

[28] Miyoshi S, Akao Y, Kuwata N et al (2014) Low-temperature protonic conduction based on surface protonics: an example of nanostructured yttria-doped zirconia. Chem Mater 26:5194-5200. https://doi.org/10.1021/cm5012923

[29] Chiodelli G, Maglia F, Anselmi-Tamburini U, Munir ZA (2009) Characterization of low temperature protonic conductivity in bulk nanocrystalline fully stabilized zirconia. Solid State Ion 180:297-301. https://doi.org/10.1016/j.ssi. 2009.02.031

[30] Kim S, Avila-Paredes HJ, Wang S et al (2009) On the conduction pathway for protons in nanocrystalline yttriastabilized zirconia. Phys Chem Chem Phys 11:3035-3038. https://doi.org/10.1039/b901623f

[31] Kim S, Anselmi-Tamburini U, Park HJ et al (2008) Unprecedented room-temperature electrical power generation using nanoscale fluorite-structured oxide electrolytes. Adv Mater 20:556-559. https://doi.org/10.1002/adma. 200700715

[32] Gregori G, Shirpour M, Maier J (2013) Proton conduction in dense and porous nanocrystalline ceria thin films. Adv Funct Mater 23:5861-5867. https://doi.org/10.1002/adfm. 201300527

[33] Takamura H, Takahashi N (2010) Electrical conductivity of dense nanocrystalline ceria under humidified atmosphere. Solid State Ion 181:100-103. https://doi.org/10.1016/j.ssi. 2009.04.017

[34] Avila-Paredes HJ, Zhao J, Wang S et al (2010) Protonic conductivity of nano-structured Yttria-stabilized zirconia: dependence on grain size. J Mater Chem 20:990-994. h ttps://doi.org/10.1039/B919100C

[35] Pérez-Coll D, Mather GC (2010) Electrical transport at low temperatures in dense nanocrystalline Gd-doped ceria. Solid State Ion 181:1033-1042. https://doi.org/10.1016/j. ssi.2009.11.017 
[36] Ruiz-Trejo E, Kilner JA (2009) Possible proton conduction in $\mathrm{Ce}_{0.9} \mathrm{Gd}_{0.1} \mathrm{O}_{2-\delta}$ nanoceramics. $\mathrm{J}$ Appl Electrochem 39:523-528. https://doi.org/10.1007/s10800-008-9713-1

[37] Maglia F, Tredici IG, Spinolo G, Anselmi-Tamburini U (2012) Low temperature proton conduction in bulk nanometric $\mathrm{TiO}_{2}$ prepared by high-pressure field assisted sintering. J Mater Res 27:1975-1981. https://doi.org/10.1557/ jmr.2012.158

[38] Gui D, Zheng T, Xie J et al (2016) Significantly dense twodimensional hydrogen-bond network in a layered zirconium phosphate leading to high proton conductivities in both water-assisted low-temperature and anhydrous intermediate-temperature regions. Inorg Chem 55:12508-12511. h ttps://doi.org/10.1021/acs.inorgchem.6b02308

[39] Dobrovolsky Y, Leonova L, Nadkhina S, Panina N (1999) Low-temperature proton conductivity in hydrated and nonhydrated tin dioxide. Solid State Ion 119:275-279. h ttps://doi.org/10.1016/S0167-2738(98)00514-1

[40] Wei T, Zhang LA, Chen Y et al (2017) Promising proton conductor for intermediate-temperature fuel cells: $\mathrm{Li}_{13.9-}$ $\mathrm{Sr}_{0.1} \mathrm{Zn}\left(\mathrm{GeO}_{4}\right)_{4}$. Chem Mater 29:1490-1495. https://doi.or g/10.1021/acs.chemmater.6b03471

[41] Zhou Y, Guan X, Zhou H et al (2016) Strongly correlated perovskite fuel cells. Nature 534:231-234. https://doi.org/ 10.1038/nature17653

[42] Brunauer S, Emmett PH, Teller E (1938) Adsorption of gases in multimolecular layers. J Am Chem Soc 60:309-319. https://doi.org/10.1021/ja01269a023

[43] Langmuir I (1916) the constitution and fundamental properties of solids and liquids. Part I solids. J Am Chem Soc 38:2221-2295. https://doi.org/10.1021/ja02268a002

[44] Stub SØ, Vøllestad E, Norby T (2017) Mechanisms of protonic surface transport in porous oxides: example of YSZ. J Phys Chem C 121:12817-12825. https://doi.org/10. 1021/acs.jpcc.7b03005

[45] Asay DB, Kim SH (2005) Evolution of the adsorbed water layer structure on silicon oxide at room temperature. J Phys Chem B 109:16760-16763. https://doi.org/10.1021/ jp053042o

[46] Kreuer K (1999) Aspects of the formation and mobility of protonic charge carriers and the stability of perovskite-type oxides. Solid State Ion 125:285-302. https://doi.org/10.10 16/S0167-2738(99)00188-5

[47] Kreuer K (1995) H/D isotope effect of proton conductivity and proton conduction mechanism in oxides. Solid State Ion 77:157-162. https://doi.org/10.1016/0167-2738(94)00 265-T

[48] Świerczek K, Skubida W (2017) Optimization of proton conductors for application in solid oxide fuel cell technology. E3S Web Conf 14:01044-01054. https://doi. org/10.1051/e3sconf/20171401044

[49] Nowick A, Vaysleyb A (1997) Isotope effect and proton hopping in high-temperature protonic conductors. Solid State Ion 97:17-26. https://doi.org/10.1016/S0167-2738(9 7)00081-7

[50] Bonanos N, Huijser A, Poulsen FW (2015) H/D isotope effects in high temperature proton conductors. Solid State Ion 275:9-13. https://doi.org/10.1016/j.ssi.2015.03.028

[51] Uchida $\mathrm{H}$ (1989) Formation of protons in $\mathrm{SrCeO}_{3}$-based proton conducting oxides. Part II. Evaluation of proton concentration and mobility in $\mathrm{Yb}$-doped $\mathrm{SrCeO}_{3}$. Solid State Ion 36:89-95. https://doi.org/10.1016/0167-2738(89) 90065-9

[52] Bonanos N (2001) Oxide-based protonic conductors: point defects and transport properties. Solid State Ion 145:265-274. https://doi.org/10.1016/S0167-2738(01)009 $51-1$

[53] Nowick A (1995) High-temperature protonic conductors with perovskite-related structures. Solid State Ion 77:137-146. https://doi.org/10.1016/0167-2738(94)00230$\mathrm{P}$

[54] Kreuer KD, Adams S, Münch W et al (2001) Proton conducting alkaline earth zirconates and titanates for high drain electrochemical applications. Solid State Ion 145:295-306. https://doi.org/10.1016/S0167-2738(01)00953-5

[55] Yamazaki Y, Babilo P, Haile SM (2008) Defect chemistry of Yttrium-doped barium zirconate: a thermodynamic analysis of water uptake. Chem Mater 20:6352-6357. h ttps://doi.org/10.1021/cm800843s

[56] Haile SM, Staneff G, Ryu KH (2001) Non-stoichiometry, grain boundary transport and chemical stability of proton conducting perovskites. J Mater Sci 36:1149-1160. http s://doi.org/10.1023/A:1004877708871

[57] Kreuer KD (2003) Proton-conducting oxides. Ann Rev Mater Res 33:333-359. https://doi.org/10.1146/annurev.ma tsci.33.022802.091825

[58] Uchida H (1983) Relation between proton and hole conduction in $\mathrm{SrCeO}_{3}$-based solid electrolytes under watercontaining atmospheres at high temperatures. Solid State Ion 11:117-124. https://doi.org/10.1016/0167-2738(83)90 048-6

[59] Malavasi L, Fisher CAJ, Islam MS (2010) Oxide-ion and proton conducting electrolyte materials for clean energy applications: structural and mechanistic features. Chem Soc Rev 39:4370-4387. https://doi.org/10.1039/b915141a

[60] Bielecki J, Parker SF, Mazzei L et al (2016) Structure and dehydration mechanism of the proton conducting oxide $\mathrm{Ba}_{2} \mathrm{In}_{2} \mathrm{O}_{5}\left(\mathrm{H}_{2} \mathrm{O}\right)_{x}$. J Mater Chem A 4:1224-1232. https://d oi.org/10.1039/C5TA05728K 
[61] Avila-Paredes HJ, Barrera-Calva E, Anderson HU et al (2010) Room-temperature protonic conduction in nanocrystalline films of yttria-stabilized zirconia. J Mater Chem 20:6235-6238. https://doi.org/10.1039/c0jm00051e

[62] Guo X (1999) On the degradation of zirconia ceramics during low-temperature annealing in water or water vapor. J Phys Chem Solids 60:539-546. https://doi.org/10.1016/ S0022-3697(98)00301-1

[63] Anselmi-Tamburini U, Maglia F, Chiodelli G et al (2006) Enhanced low-temperature protonic conductivity in fully dense nanometric cubic Zirconia. Appl Phys Lett 89:163116-163118. https://doi.org/10.1063/1.2360934

[64] Miyoshi S, Akao Y, Kuwata N et al (2012) Water uptake and conduction property of nano-grained yttria-doped zirconia fabricated by ultra-high pressure compaction at room temperature. Solid State Ion 207:21-28. https://doi.org/10. 1016/j.ssi.2011.11.014

[65] Jing Y, Matsumoto H, Aluru NR (2018) Mechanistic insights into hydration of solid oxides. Chem Mater 30:138-144. https://doi.org/10.1021/acs.chemmater.7b 03476

[66] Tret'yakov NE, Filimonov VN (1972) Relative protondonor capacity of hydroxyl groups of surface oxides studied by an ir-spectroscopic method. Kinet Katal 13:815-823

[67] Holmes HF, Fuller EL, Gammage RB (1972) Heats of immersion in the zirconium oxide-water system. J Phys Chem 76:1497-1502. https://doi.org/10.1021/j100654a023

[68] Yamada M, Wei M, Honma I, Zhou H (2006) One-dimensional proton conductor under high vapor pressure condition employing titanate nanotube. Electrochem Commun 8:1549-1552. https://doi.org/10.1016/j.elecom.2006.0 7.020

[69] Iwahara H, Esaka T, Uchida H, Maeda N (1981) Proton conduction in sintered oxides and its application to steam electrolysis for hydrogen production. Solid State Ion 3-4:359-363. https://doi.org/10.1016/0167-2738(81)90113 $-2$

[70] Norby T (1999) Solid-state protonic conductors: principles, properties, progress and prospects. Solid State Ion 125:1-11. https://doi.org/10.1016/S0167-2738(99)00152-6

[71] Iwahara H (1996) Proton conducting ceramics and their applications. Solid State Ion 86-88:9-15. https://doi.org/10. 1016/0167-2738(96)00087-2

[72] Haile SM, West DL, Campbell J (1998) The role of microstructure and processing on the proton conducting properties of gadolinium-doped barium cerate. J Mater Res 13:1576-1595. https://doi.org/10.1557/JMR.1998.0219

[73] Christie G (1996) Microstructure: ionic conductivity relationships in ceria-gadolinia electrolytes. Solid State Ion 83:17-27. https://doi.org/10.1016/0167-2738(95)00155-7
[74] Nafe $\mathrm{H}$ (1984) Ionic conductivity of $\mathrm{ThO}_{2}$ - and $\mathrm{ZrO}_{2}$-based electrolytes between 300 and $2000 \mathrm{~K}$. Solid State Ion 13:255-263. https://doi.org/10.1016/0167-2738(84)900407

[75] Braun A, Duval S, Ried P et al (2009) Proton diffusivity in the $\mathrm{BaZr}_{0.9} \mathrm{Y}_{0.1} \mathrm{O}_{3-\delta}$ proton conductor. J Appl Electrochem 39:471-475. https://doi.org/10.1007/s10800-008-9667-3

[76] Shirpour M, Merkle R, Lin CT, Maier J (2012) Nonlinear electrical grain boundary properties in proton conducting $\mathrm{Y}-\mathrm{BaZrO}_{3}$ supporting the space charge depletion model. Phys Chem Chem Phys 14:730-740. https://doi.org/10.10 39/C1CP22487E

[77] Kjølseth C, Fjeld H, Prytz Ø et al (2010) Space-charge theory applied to the grain boundary impedance of proton conducting $\mathrm{BaZr}_{0.9} \mathrm{Y}_{0.1} \mathrm{O}_{3-\delta}$. Solid State Ion 181:268-275. https://doi.org/10.1016/j.ssi.2010.01.014

[78] Park HJ, Kwak C, Lee KH et al (2009) Interfacial protonic conduction in ceramics. J Eur Ceram Soc 29:2429-2437. h ttps://doi.org/10.1016/j.jeurceramsoc.2009.02.010

[79] Guo X, Waser R (2006) Electrical properties of the grain boundaries of oxygen ion conductors: acceptor-doped zirconia and ceria. Prog Mater Sci 51:151-210. https://doi. org/10.1016/j.pmatsci.2005.07.001

[80] Kliewer KL, Koehler JS (1965) Space charge in ionic crystals. I. General approach with application to $\mathrm{NaCl}$. Phys Rev 140:A1226-A1240. https://doi.org/10.1103/PhysRev. 140.A1226

[81] Guo X, Maier J (2001) Grain boundary blocking effect in Zirconia: a Schottky barrier analysis. J Electrochem Soc 148:E121-E126. https://doi.org/10.1149/1.1348267

[82] Lee JS, Anselmi-Tamburini U, Munir ZA, Kim S (2006) Direct evidence of electron accumulation in the grain boundary of yttria-doped nanocrystalline Zirconia ceramics. Electrochem Solid-State Lett 9:J34-J36. https://doi.org/ 10.1149/1.2208012

[83] De Souza RA, Pietrowski MJ, Anselmi-Tamburini U et al (2008) Oxygen diffusion in nanocrystalline yttria-stabilized zirconia: the effect of grain boundaries. Phys Chem Chem Phys 10:2067. https://doi.org/10.1039/b719363g

[84] Tschöpe A (2001) Grain size-dependent electrical conductivity of polycrystalline cerium oxide II: space charge model. Solid State Ion 139:267-280. https://doi.org/10.10 16/S0167-2738(01)00677-4

[85] Kim S, Fleig J, Maier J (2003) Space charge conduction: simple analytical solutions for ionic and mixed conductors and application to nanocrystalline ceria. Phys Chem Chem Phys 5:2268-2273. https://doi.org/10.1039/B300170A

[86] Iwahara H, Yajima T, Hibino T et al (1993) Protonic conduction in calcium, strontium and barium zirconates. Solid 
State Ion 61:65-69. https://doi.org/10.1016/0167-2738(93) 90335-Z

[87] Yajima T, Suzuki H, Yogo T, Iwahara H (1992) Protonic conduction in $\mathrm{SrZrO}_{3}$-based oxides. Solid State Ion 51:101-107. https://doi.org/10.1016/0167-2738(92)90351$\mathrm{O}$

[88] Yajima T, Kazeoka H, Yogo T, Iwahara H (1991) Proton conduction in sintered oxides based on $\mathrm{CaZrO}_{3}$. Solid State Ion 47:271-275. https://doi.org/10.1016/0167-2738(91)90 249-B

[89] Münch W, Kreuer KD, Adams et al (1999) The relation between crystal structure and the formation and mobility of protonic charge carriers in perovskite-type oxides: a case study of Y-doped $\mathrm{BaCeO}_{3}$ and $\mathrm{SrCeO}_{3}$. Phase Trans 68:567-586. https://doi.org/10.1080/01411599908224535

[90] Singh K, Kannan R, Thangadurai V (2016) Synthesis and characterisation of ceramic proton conducting perovskitetype multi-element-doped $\mathrm{Ba}_{0.5} \mathrm{Sr}_{0.5} \mathrm{Ce}_{1-\mathrm{x}-\mathrm{y}-\mathrm{z}} \mathrm{Zr}_{\mathrm{x}} \mathrm{Gd}_{\mathrm{y}} \mathrm{Y}_{\mathrm{z}}$ $\mathrm{O}_{3-\delta}(0<\mathrm{x}<0.5 ; \mathrm{y}=0,0.1,0.15 ; \mathrm{z}=0.1,0.2)$. Int $\mathrm{J}$ Hydrogen Energy 41:13227-13237. https://doi.org/10.101 6/j.ijhydene.2016.05.089

[91] Corcoran DJ, Irvine JT (2001) Investigations into $\mathrm{Sr}_{3-}$ $\mathrm{CaZr}_{0.5} \mathrm{Ta}_{1.5} \mathrm{O}_{8.75}$, a novel proton conducting perovskite oxide. Solid State Ion 145:307-313. https://doi.org/10.101 6/S0167-2738(01)00955-9

[92] Ahmed I, Eriksson S, Ahlberg E et al (2006) Synthesis and structural characterization of perovskite type proton conducting $\mathrm{BaZr}_{1-\mathrm{x}} \mathrm{In}_{\mathrm{x}} \mathrm{O}_{3-\delta}(0.0 \leq \mathrm{x} \leq 0.75)$. Solid State Ion 177:1395-1403. https://doi.org/10.1016/j.ssi.2006.07.009

[93] Ding H, Lin B, Fang D et al (2009) $\mathrm{BaZr}_{0.1} \mathrm{Ce}_{0.7} \mathrm{Y}_{0.2} \mathrm{O}_{3-\delta}$ proton-conducting electrolyte prepared by gel-casting for low-temperature solid oxide fuel cells. J Alloy Compd 474:364-369. https://doi.org/10.1016/j.jallcom.2008.06. 106

[94] Khani Z, Taillades-Jacquin M, Taillades G et al (2009) New synthesis of nanopowders of proton conducting materials. A route to densified proton ceramics. J Solid State Chem 182:790-798. https://doi.org/10.1016/j.jssc.2008.12.020

[95] Ahmed I, Kinyanjui FG, Steegstra P et al (2010) Improved proton conductivity in spark-plasma sintered dense ceramic $\mathrm{BaZr}_{0.5} \mathrm{In}_{0.5} \mathrm{O}_{3-\delta}$. Electrochem Solid State Lett 13:B130B134. https://doi.org/10.1149/1.3482016

[96] Barison S, Battagliarin M, Cavallin T et al (2008) Barium non-stoichiometry role on the properties of $\mathrm{Ba}_{1+x} \mathrm{Ce}_{0.65}$ $\mathrm{Zr}_{0.20} \mathrm{Y}_{0.15} \mathrm{O}_{3-\delta}$ proton conductors for IT-SOFCs. Fuel Cells 8:360-368. https://doi.org/10.1002/fuce.200800021

[97] Świerczek K, Skubida W, Niemczyk A et al (2017) Structure and transport properties of proton-conducting $\mathrm{BaSn}_{0.5} \mathrm{In}_{0.5} \mathrm{O}_{2.75} \quad$ and $\quad$ A-site substituted
$\mathrm{Ba}_{0.9} \mathrm{Ln}_{0.1} \mathrm{Sn}_{0.5} \mathrm{In}_{0.5} \mathrm{O}_{2.8}(\mathrm{Ln}=\mathrm{La}, \mathrm{Gd})$ oxides. Solid State Ion 307:44-50. https://doi.org/10.1016/j.ssi.2017.05.010

[98] Świerczek K, Zając W, Klimkowicz A et al (2015) Crystal structure and proton conductivity in highly oxygen-deficient $\mathrm{Ba}_{1-\mathrm{x}} \mathrm{La}_{\mathrm{x}}(\mathrm{In}, \mathrm{Zr}, \mathrm{Sn}) \mathrm{O}_{3-\delta}$ perovskites. Solid State Ion 275:58-61. https://doi.org/10.1016/j.ssi.2015.02.018

[99] Bohn HG, Schober T (2000) Electrical conductivity of the high-temperature proton conductor $\mathrm{BaZr}_{0.9} \mathrm{Y}_{0.1} \mathrm{O}_{2.95}$. J Am Ceram Soc 83:768-772. https://doi.org/10.1111/j.1151-29 16.2000.tb01272.x

[100] Iguchi F, Sata N, Tsurui T, Yugami H (2007) Microstructures and grain boundary conductivity of $\mathrm{BaZr}_{1-\mathrm{x}} \mathrm{Y}_{\mathrm{x}} \mathrm{O}_{3}$ $(\mathrm{x}=0.05, \quad 0.10,0.15) \quad$ ceramics. Solid State Ion 178:691-695. https://doi.org/10.1016/j.ssi.2007.02.019

[101] Cervera R, Oyama Y, Miyoshi S et al (2008) Structural study and proton transport of bulk nanograined Y-doped $\mathrm{BaZrO3}$ oxide protonics materials. Solid State Ion 179:236-242. https://doi.org/10.1016/j.ssi.2008.01.082

[102] Tao S, Irvine JTS (2007) Conductivity studies of dense yttrium-doped $\mathrm{BaZrO}_{3}$ sintered at $1325{ }^{\circ} \mathrm{C}$. J Solid State Chem 180:3493-3503. https://doi.org/10.1016/j.jssc.2007. 09.027

[103] Ryu KH, Haile SM (1999) Chemical stability and proton conductivity of doped $\mathrm{BaCeO}_{3}-\mathrm{BaZrO}_{3}$ solid solutions. Solid State Ion 125:355-367. https://doi.org/10.1016/S016 7-2738(99)00196-4

[104] Azad A, Irvine J (2007) Synthesis, chemical stability and proton conductivity of the perovksites $\mathrm{Ba}(\mathrm{Ce}, \mathrm{Zr})_{1-\mathrm{x}} \mathrm{Sc}_{\mathrm{x}-}$ $\mathrm{O}_{3-\delta}$. Solid State Ion 178:635-640. https://doi.org/10.101 6/j.ssi.2007.02.004

[105] Potter A, Baker R (2006) Impedance studies on $\mathrm{Pt}$ $\left|\mathrm{SrCe}_{0.95} \mathrm{Yb}_{0.05} \mathrm{O} 3\right| \mathrm{Pt}$ under dried and humidified air, argon and hydrogen. Solid State Ion 177:1917-1924. https://doi. org/10.1016/j.ssi.2006.06.022

[106] Li YM, Hibino M, Miyayania M, Kudo T (2000) Proton conductivity of tungsten trioxide hydrates at intermediate temperature. Solid State Ion 134:271-279

[107] England W, Cross M, Hamnett A et al (1980) Fast proton conduction in inorganic ion-exchange compounds. Solid State Ion 1:231-249. https://doi.org/10.1016/0167-2738(8 0)90007-7

[108] Schoonman J (2000) Nanostructured materials in solid state ionics. Solid State Ion 135:5-19. https://doi.org/10.1016/ S0167-2738(00)00324-6

[109] Tuller H (2000) Ionic conduction in nanocrystalline materials. Solid State Ion 131:143-157. https://doi.org/10.1016/ S0167-2738(00)00629-9

[110] Dawson JA, Tanaka I (2014) Proton incorporation and trapping in $\mathrm{ZrO}_{2}$ grain boundaries. J Mater Chem A 2:1400-1408. https://doi.org/10.1039/C3TA14029F 
[111] Maglia F, Tredici IG, Spinolo G, Anselmi-Tamburini U (2012) Low temperature proton conduction in bulk nanometric $\mathrm{TiO} 2$ prepared by high-pressure field assisted sintering. J Mater Res 27:1975-1981. https://doi.org/10.1557/ jmr.2012.158

[112] Sun W, Fang S, Yan L, Liu W (2012) Investigation on proton conductivity of $\mathrm{La}_{2} \mathrm{Ce}_{2} \mathrm{O}_{7}$ in wet atmosphere: dependence on water vapor partial pressure. Fuel Cells 12:457-463. https://doi.org/10.1002/fuce.201100175

[113] Zhu Z, Liu B, Shen J et al (2016) $\mathrm{La}_{2} \mathrm{Ce}_{2} \mathrm{O}_{7}$ : a promising proton ceramic conductor in hydrogen economy. J Alloy Compd 659:232-239. https://doi.org/10.1016/j.jallcom.20 15.11 .041

[114] Besikiotis V, Knee CS, Ahmed I et al (2012) Crystal structure, hydration and ionic conductivity of the inherently oxygen-deficient $\mathrm{La}_{2} \mathrm{Ce}_{2} \mathrm{O}_{7}$. Solid State Ion 228:1-7. http s://doi.org/10.1016/j.ssi.2012.08.023

[115] Besikiotis V, Ricote S, Jensen MH et al (2012) Conductivity and hydration trends in disordered fluorite and pyrochlore oxides: a study on lanthanum cerate-zirconate based compounds. Solid State Ion 229:26-32. https://doi. org/10.1016/j.ssi.2012.10.004

[116] Hui R, Maric R, Decès-Petit C et al (2006) Proton conduction in ceria-doped $\mathrm{Ba}_{2} \operatorname{In}_{2} \mathrm{O}_{5}$ nanocrystalline ceramic at low temperature. J Power Sour 161:40-46. https://doi.org/ 10.1016/j.jpowsour.2006.03.070

[117] Nogami M, Matsushita H, Goto Y, Kasuga T (2000) A solgel-derived glass as a fuel cell electrolyte. Adv Mater 12:1370-1372. https://doi.org/10.1002/1521-4095(200009) 12:18\%3c1370:AID-ADMA1370\%3e3.0.CO;2-1

[118] Uma T, Nogami M (2006) On the development of proton conducting $\mathrm{P}_{2} \mathrm{O}_{5}-\mathrm{ZrO}_{2}-\mathrm{SiO}_{2}$ glasses for fuel cell electrolytes. Mater Chem Phys 98:382-388. https://doi.org/10. 1016/j.matchemphys.2005.09.049

[119] Haile SM, Boysen DA, Chisholm CRI, Merle RB (2001) Solid acids as fuel cell electrolytes. Nature 410:910-913. h ttps://doi.org/10.1038/35073536

[120] Shen Y, Nishida M, Kanematsu W, Hibino T (2011) Synthesis and characterization of dense $\mathrm{SnP} 2 \mathrm{O}_{7}-\mathrm{SnO}_{2}$ composite ceramics as intermediate-temperature proton conductors. J Mater Chem 21:663-670. https://doi.org/10. 1039/C0JM02596H

[121] Xu X, Tao S, Wormald P, Irvine JTS (2010) Intermediate temperature stable proton conductors based upon $\mathrm{SnP}_{2} \mathrm{O}_{7}$, including additional $\mathrm{H}_{3} \mathrm{PO}_{4}$. J Mater Chem 20:7827. http s://doi.org/10.1039/c0jm01089h

[122] Paschos O, Kunze J, Stimming U, Maglia F (2011) A review on phosphate based, solid state, protonic conductors for intermediate temperature fuel cells. J Phys Condens
Matter 23:234110-234135. https://doi.org/10.1088/0953-8 $984 / 23 / 23 / 234110$

[123] Martsinkevich VV, Ponomareva VG (2012) Double salts $\mathrm{Cs}_{1-\mathrm{x}} \mathrm{M}_{\mathrm{x}} \mathrm{H}_{2} \mathrm{PO}_{4}(\mathrm{M}=\mathrm{Na}, \mathrm{K}, \mathrm{Rb})$ as proton conductors. Solid State Ion 225:236-240. https://doi.org/10.1016/j.ssi. 2012.04.016

[124] Matsui T, Kukino T, Kikuchi R, Eguchi K (2005) An intermediate temperature proton-conducting electrolyte based on a $\mathrm{CsH}_{2} \mathrm{PO}_{4} / \mathrm{SiP}_{2} \mathrm{O}_{7}$ composite. Electrochem Solid-State Lett 8:A256-A258. https://doi.org/10.1149/1. 1883906

[125] Chen X, Wang C, Payzant EA et al (2008) An oxide ion and proton Co-ion conducting $\mathrm{Sn}_{0.9} \mathrm{In}_{0.1} \mathrm{P}_{2} \mathrm{O}_{7}$ electrolyte for intermediate-temperature fuel cells. J Electrochem Soc 155:B1264-B1269. https://doi.org/10.1149/1.2988135

[126] Le M-V, Tsai D-S, Yang C-Y et al (2011) Proton conductors of cerium pyrophosphate for intermediate temperature fuel cell. Electrochim Acta 56:6654-6660. https://doi.org/10.1 016/j.electacta.2011.05.040

[127] Aoki Y, Harada A, Nakao A et al (2012) Percolative proton conductivity of sol-gel derived amorphous aluminosilicate thin films. Phys Chem Chem Phys 14:2735-2742. https://d oi.org/10.1039/c2cp23821g

[128] Kojo G, Shono Y, Ushiyama H et al (2017) Influence of La/ $\mathrm{W}$ ratio on electrical conductivity of lanthanum tungstate with high La/W ratio. J Solid State Chem 248:1-8. https://d oi.org/10.1016/j.jssc.2017.01.011

[129] Tandé C, Pérez-Coll D, Mather GC (2012) Surface proton conductivity of dense nanocrystalline YSZ. J Mater Chem 22:11208. https://doi.org/10.1039/c2jm31414b

[130] Mazaheri M, Razavi Hesabi Z, Sadrnezhaad SK (2008) Two-step sintering of titania nanoceramics assisted by anatase-to-rutile phase transformation. Scripta Mater 59:139-142. https://doi.org/10.1016/j.scriptamat.2008.02. 041

[131] Weibel A, Bouchet R, Denoyel R, Knauth P (2007) Hot pressing of nanocrystalline $\mathrm{TiO} 2$ (anatase) ceramics with controlled microstructure. J Eur Ceram Soc 27:2641-2646. https://doi.org/10.1016/j.jeurceramsoc.2006.11.073

[132] Anselmi-Tamburini U, Garay JE, Munir ZA (2006) Fast low-temperature consolidation of bulk nanometric ceramic materials. Scripta Mater 54:823-828. https://doi.org/10.10 16/j.scriptamat.2005.11.015

[133] Hinterberg J, Adams A, Blümich B et al (2013) 1H-NMR measurements of proton mobility in nano-crystalline YSZ. Phys Chem Chem Phys 15:19825-19830. https://oi.org/ 10.1039/c3cp53039f

[134] Buscaglia V, Viviani M, Buscaglia MT et al (2004) Nanostructured barium titanate ceramics. Powder Technol 148:24-27. https://doi.org/10.1016/j.powtec.2004.09.016 
[135] Xiao CJ, Li ZX, Deng XR (2011) Grain-size effects on thermal properties of $\mathrm{BaTiO}_{3}$ ceramics. Bull Mater Sci 34:963-966. https://doi.org/10.1007/s12034-011-0222-1

[136] Shabanikia A, Javanbakht M, Amoli HS et al (2014) Effect of $\mathrm{La}_{2} \mathrm{Ce}_{2} \mathrm{O}_{7}$ on the physicochemical properties of phosphoric acid doped polybenzimidazole nanocomposite membranes for high temperature proton exchange membrane fuel cells applications. J Electrochem Soc 161:F1403-F1408. https://doi.org/10.1149/2.0561414jes

[137] Sakthivel M, Weppner W (2007) Hydrogen sensing based on proton and electron transport across and along the interface solid oxide electrolyte-platinum electrode. J Phys D Appl Phys 40:7210-7216. https://doi.org/10.1088/0022$3727 / 40 / 23 / \mathrm{S} 04$

[138] Kreuer KD (2003) Proton-conducting oxides. Ann Rev Mater Res 33:333-359. https://doi.org/10.1146/annurev.ma tsci.33.022802.091825

Publisher's Note Springer Nature remains neutral with regard to jurisdictional claims in published maps and institutional affiliations. 